\title{
Regulation and regulatory effectiveness in public health
}

\section{GUEST EDITOR}

\section{Stephen J. Corbett}

Centre for Population Health, Sydney West Area Health Service

Email: stephen_corbett@wsahs.nsw.gov.au

Much of the global success of 19th century sanitary reform in developed economies was built upon the prescriptive, but effective, regulation of: urban water quality and sewage disposal; food safety; burials and mortuaries; noxious trades; and housing and building standards. ${ }^{1}$ Within New South Wales (NSW) these regulations were supported by a trained inspectorate and a system of governance at local government level, which endured more or less unchanged for 100 years after the first NSW Public Health Act of 1896.

Since the 1970s, regulatory modernisation in all arms of government has been driven by a need to reduce administrative red tape without compromising regulatory effectiveness. This modernisation accepted that regulators would be more likely to succeed by being responsive to the context, conduct and culture of those being regulated, and by invoking escalating sanctions; that is, soft words before hard words, and carrots before sticks. ${ }^{2}$

Health departments have been slow to embrace regulatory reform, perhaps because many of these regulatory activities are now marginal and, to a degree, alien to the culture of health-care delivery. It is, however, significant that regulatory reform has transformed the domains of environment protection, food safety and occupational health and safety, all of which originated in health departments and continue to have primary public health objectives.

This transformation began with the publication of the Robens Report in the United Kingdom in the 1970s. ${ }^{3}$ Robens argued that occupational health and safety regulation had become a complex mass of technical rules for workers to follow and inspectors to enforce. Not only were the regulations not understood by workers, they also undermined responsibility for safety throughout organisations by inviting the impression that safety was imposed from outside the workplace. ${ }^{4}$ As a result of regulatory reform, organisations were to be given general duties of care for their employees' occupational health and safety. Such duties were to be discharged by collaborating with the workforce to develop, document, implement and improve auditable safety management systems.

The new style of regulation seeks to use its power of command in a way that is more analogous to good management - it seeks to encourage excellence at the same time as setting a standard, below which performance shall not fall.

Responsive regulation can be viewed as a regulatory pyramid comparable to the principle of a hierarchy of control of occupational or environmental hazards: ${ }^{5}$

- Voluntarism is based on an individual or organisational undertaking to do the right thing without any coercion.

- Self-regulation occurs where an organised group regulates the behaviour of its members (e.g. by establishing an industry-level code of practice).

- Economic instruments involve economic sanctions or incentives, or measures that give more power to consumers. 
- Meta-regulation involves an external regulatory body (e.g. ensuring that health-care providers implement safety and quality programs and practices).

- Command and control involves enforcement by government (e.g. ensuring compliance with rules for licensing facilities).

Over the last few years, some of these principles of responsive regulation and modern approaches to regulatory governance have found application not only in the more traditional public health fields such as environmental health, but also in areas as diverse as clinical safety and quality and research governance.

This edition of the Bulletin includes articles demonstrating the successful contribution of regulatory governance to public health. Byleveld and others assess the impact over the last 7 years of a responsive, regulatory framework to improve the quality of drinking water in rural NSW; Bloom and Frew outline the gains made in the regulation of clinical research. These contributions share the conclusion that the application of frameworks and systems rather than an elaborate and prescriptive list of requirements are vital to effective regulation.

Tutt provides a local perspective of tobacco control in his report of the enforcement of laws related to selling tobacco products to minors. He reminds us that all regulatory effort must be accompanied by the support of field staff in what is sometimes difficult work and by a commitment to the ongoing evaluation of the effectiveness of regulatory programs.

There is a need for constant vigilance and innovation in the development of public health regulatory frameworks. The regulation of the built environment has been a cornerstone of public health practice, but both technological progress and the increasing importance of chronic disease prevention are changing the nature of this task. I have discussed this aspect of public health regulation in a separate article.
Using the example of proposed future directions in tobacco regulation, especially the adoption of economic instruments to regulate unhealthy products, Penman provides some important and timely insights into how regulatory initiatives in public health should be framed so that they attract the support both of the community and our political representatives.

Regulation has become more common with the growth of private entrepreneurs and the introduction of market mechanisms into the public sector. These new bodies are seeking flexible, participatory and devolved forms of regulation, in addition to traditional enforcement such as inspections. ${ }^{5}$ A review of the NSW Public Health Act 1991 is currently underway and the articles in this issue provide some evidence of the growing awareness of both the utility and possibilities of modernised and effective public health regulation.

\section{References}

1. Hamlin C, Sheard S. Revolutions in public health: 1848, and 1998? BMJ 1998; 317: 587-91.

2. Ayres I, Braithwaite J. Responsive regulation: transcending the deregulation debate. New York: Oxford University Press; 1992.

3. Committee on Safety. Health at Work (Robens Committee). Safety and Health at Work: Report of the Committee 1970-72. London: HMSO; 1972.

4. Gruen N. Regulating for innovation. Centre for Policy Development. Sydney: Centre for Policy Development; 2008. Available at: http://cpd.org.au/article/regulating-innovation (Cited 10 November 2008.)

5. Braithwaite J, Healy J, Dwan K. The Governance of Health Safety and Quality. Canberra: Commonwealth of Australia; 2005. Available at: http://reghealth.anu.edu.au/menus/link_ documents/Braithwaite\%20et\%20al\%20governance0705.pdf (Cited 10 November 2008.) 


\section{Regulation for chronic disease control: the pathfinder role of tobacco}

\section{Andrew Penman}

The Cancer Council NSW

Email: andrewp@nswcc.org.au

\begin{abstract}
Regulation for health in the modern era has its foundations in the English Public Health Act of 1848. Early legislation was concerned with controlling environmental causes of disease. However, the focus on regulation today within health departments has diminished, displaced by a focus on services and related programs. The regulatory debate is now centred on what degree of protection, or safety margin, is required, and how regulatory efficiency may be improved. The example of tobacco control is reviewed to show how regulation can play a large role in chronic disease control, and consideration given to how regulatory tools could be further diversified and regulatory effectiveness improved.
\end{abstract}

Regulation for health in the modern era has its foundations in the English Public Health Act of 1848 and the imprint of this legislation can still be found in legislation of most jurisdictions formerly under the British Empire. The miasma theory of disease was then accepted wisdom and legislation was concerned with controlling environmental causes of disease and conferring the powers required to do so. Public Health Acts have retained their focus on health protection, i.e. on controlling the microbial, physical, toxic and xenobiotic causes of disease.

Containing the potential for these hazards to cause disease remains essential, but the regulatory debate focuses around how great a degree of protection, or safety margin, is required and how regulatory efficiency may be improved. Functions integral to early boards of health, such as building regulation, have been spun off to other agencies. In consequence, the focus within health departments on the regulatory craft has diminished, displaced by a focus on health services and related programs.
Population health goals in the early 21 st century mostly focus on reducing mortality from chronic disease and the compression of associated morbidity. ${ }^{1}$ These conditions share common proximate risk factors rooted in lifestyle. Health promotion developed largely to change lifestyle behaviours through education and social change - a change mediated though information, services, the built environment and organisational practice. In this paradigm, the role of health protection, or health regulation, has been minimised, and the title given to the frontline warrior of the first public health act - Inspector of Public Nuisances seems out of place in these more egalitarian times.

\section{Developments in health regulation}

Health promotion has resulted in a more explicit understanding of the diversity of the health environment and recognition that individual behaviour is profoundly affected by social context. Human behaviour and the environment interact, and environmental regulation can play an important role in chronic disease control. This understanding has required an evolution in the philosophy and practice of health regulation. The story of tobacco control illustrates the role that regulation can play in modifying behaviours and lifestyles.

One development is in our understanding of chronic disease. Traditional health protection excelled at elimination of a hazardous agent at source. In chronic disease, specific regulatory measures are crafted to eliminate not the proximate cause of disease, but any of a number of contributory causes. Taken as a whole, these measures may be demonstrably effective in reducing risk, but the contribution of any single measure may be moderate to minor. Advertising bans, tax increases, smoke-free public places, on-pack warnings and point-of-sale restrictions have all contributed to smoking abatement. Although evidence can be adduced to demonstrate short-term impact on behaviour, it is more difficult to isolate the impact of each measure on smoking prevalence, and especially to predict this in advance of a regulatory decision. ${ }^{2}$ The statement, "Why don't you just ban the stuff?", heard in popular discourse on tobacco illustrates the public expectation that our measures should be more decisively effective.

Another development has been to recruit regulatory instruments from outside the health sector, appropriate to the environmental-behavioural goals. In tobacco control, taxing 
powers - state tobacco licensing fees and now federal excise - have been imposed at unprecedented levels to raise the cost of tobacco dramatically, well beyond the level needed to fund the treatment of the health consequences of smoking. Price remains one of the most effective measures for lowering smoking and consumption rates. ${ }^{3}$

A third change has been to transfer enforceable sanctions from the person who commits a hazardous act to the person who creates the circumstances that contribute. One cannot yet be personally fined just for smoking. This is not without precedent in public health law - owners as well as occupiers are enjoined to comply with controls on dwellings - but the extent to which this has been pursued in tobacco control is extraordinary. The ban on advertising in any form includes a striking assumption of powers over broadcasting, rewriting generally accepted freedoms in communication.

Many factors have contributed to the regulatory achievements in tobacco.

1. Regulation has followed rather than led social norms.

All credit here to health advocates and communicators who have transformed social consciousness on tobacco.

2. Advocacy has deliberately undermined the credibility of the tobacco industry and its influence with government, reducing the political price that government may pay for regulation.

3. Research into tobacco and tobacco control has been critical to developing the evidence base for regulation. The Cancer Council Victoria has led the world in high quality research not only in creating the case for regulatory reform, but as importantly, also in validating the outcomes of regulation.

4. Regulation is very cost-effective. Over the long term, governments have been reluctant to spend money on health promotion strategies in tobacco. One could argue for greater spending on the implementation of regulation but governments prefer measures that are inexpensive to implement.

5. Regulation leverages the effectiveness of non-regulatory strategies. It is striking how effective Australian tobacco social marketing campaigns have been despite limited expenditure compared to that in the USA. It is likely that the absence of pro-tobacco marketing in Australia lies behind this outcome.

\section{Future tobacco legislation}

Governments have treated tobacco in an exceptional way compared to products of lesser risk, like heroin in medical practice or lead in petrol, which have been scheduled or regulated to extinction. Even though it is tempting to revert to this course as the prevalence of smoking falls, it is this exceptionalism that provides some precedent for how other risks might be regulated. There are several ways in which tobacco regulation might be extended in the future while keeping it a legal product. One important feature is that the regulations reduce commercial incentives to frustrate public health goals. All have implications for the broader control of chronic disease.

\section{Licensing}

On 22 April 2008, the New South Wales (NSW) government announced a number of reforms as part of its reform package Protecting Children from Tobacco and foreshadowed a licensing system for tobacco retailers. ${ }^{4}$ Although retailer reaction has been benign, the final proposal is for a negative licensing system, conferring the power to prohibit a business from selling tobacco if, for example, it sells to minors or displays tobacco products. A future direction for health-based licensing is to mould the retail tobacco environment actively by reducing the density of retail outlets, diminishing convenience retailing and modifying the exchange that occurs within an outlet to encourage quitting - akin to converting drug pushers into habit-management agents.

\section{Statutory liability for tobacco-related harms}

The industry mantra that tobacco is a legal product is used to absolve them from product liability. When claims have been pressed in the courts, the results have been mixed and the majority of litigants are deterred by the costs.

The Dust Diseases Act is an example of how the behaviour of business can change when the balance of power is shifted in favour of the damaged party. Tobacco smoke is a dust, and to bring tobacco-related harms within the purview of this Act is scientifically defensible. The risks of commercial loss arising from litigation for product related harm are presently too low to affect the industry's returns. The imposition of liability though statute on the industry, and the simplification of the judicial path to redress, would increase the success rate of product-related claims for damages. This in turn would introduce the real risk of business loss and seriously reframe commercial incentives to sell tobacco, legal product or not.

\section{Regulating tobacco emissions}

Direct regulation of product is a long-standing tool in environmental health. Attempts to regulate tar and nicotine content of cigarettes paradoxically amplified adverse health effects through industry manipulation of the performance characteristics of cigarettes. ${ }^{5}$ There is good evidence that cigarettes differ in hazard profile and proposals are afoot to reduce the toxicity of the combusted unit through product regulation. ${ }^{5}$ But anticipating the population impact of changes to a tobacco stick is error prone and because the industry enjoys a scientific and technical advantage over the regulator, it may again frustrate renewed attempts to regulate toxins in cigarettes. ${ }^{6}$ An alternative approach may be to take a leaf out of environmental 
regulation and license tobacco companies to pollute. This shifts the focus of regulation from the uncertainties of individual dose exposure and harms to population exposure. It could be accomplished by transforming the current excise regime into a Pareto tax imposed on cigarette emissions, weighted according to the harmfulness of specific constituents. $^{7}$ (A Pareto tax - or Pareto efficient tax - is one designed to redistribute economic allocations or outputs so as to optimise welfare. The point at which no further welfare gains can be made from further redistributions is termed the Pareto optimum.) With the imposition of penalties, the same system could be used to cap the aggregate weighted emissions delivered into the lungs of Australians and lower this cap progressively. ${ }^{8}$ While the idea of positively sanctioning commercial trade in deadly products may appal some, it has the virtue of improving on the current situation where the tobacco industry has an unfettered licence to pollute the lungs of Australians. The effect of this change would be to turn the science and product development endeavours of a powerful industry somewhat more towards meeting rather than frustrating public health goals.

\section{Compulsory acquisition of commercial information}

Information asymmetry is an impediment to evidencebased public health practice. The expenditure and efforts of health agencies and public health researchers to understand, anticipate and respond to the tobacco epidemic are puny compared to the information and research amassed by the tobacco industry. A requirement that all information on product and the market be made available to public health agencies for tobacco-control purposes could stop this cat and mouse game.

\section{Shifting the incidence of costs in tobacco control}

It seems beyond argument that the tobacco industry is the principal vector in the tobacco epidemic. However, there are other players, who wittingly or unwittingly, for profit or not, play a contributory role. For example, there is strong evidence that the glamorous portrayal of smoking in movies promotes youth smoking. At the moment, the community bears the cost of countering this effect. It is open to regulators to impose this cost on the cinema, film and television industries by requiring them to run approved anti-smoking advertisements in association with movies promoting smoking. ${ }^{9}$

A great barrier to effective regulation in chronic disease lies in the social framing of propositions for state interventions in health. Health is not alone in having a culture removed from the mainstream and seen as self-referential. The acceptance of health protection in the nineteenth and early twentieth centuries rested on a particular view of the public interest - one where the measure concerned reflected an interest in common to all members of society, or at least a preponderant proportion. The perception of an imminent common threat is a powerful motivator for regulation, providing a groundswell of support even for cost-ineffective measures.

However, with hazards that are seen to involve the personal assumption of risk - be it obesity, sedentary behaviour, smoking or drinking - this view of the public interest is unsound, and opposition frames regulatory controls as a social engineering intrusion into individual rights and freedoms. The libertarian view restricts the domain of public regulation to ensuring the provision of information only and holds the unfettered exercise of private property rights as essential to liberty.

However, as Feintuck explains, at the core of democratic values is the commitment to full participation and equal standing in society. ${ }^{10}$ To the extent that private matters limit this potential, they become matters of public interest. In a capitalist democracy, although private property rights are central to the notion of liberty, the notion rests on the belief that this maximises the welfare of the community. If the exercise of this private property power results in fundamentally undemocratic outcomes, limiting the ability of others to enjoy the entitlements of citizenship and participation, then the underlying assumption is rebutted and intervention is justified. This principle is readily accepted in trade practices, anti-trust and utilities regulation. It is a driving principle in the public funding and provision of health services, but is strangely absent as a driving philosophy of health regulation. This is even stranger, perhaps, when we reflect that Edwin Chadwick came to the role of enacting the Public Health Act of 1848 from his experience as Poor Law Commissioner. He saw health regulation as a tool to address poverty and its attendant burden. As we remake public health for the challenge of preventing chronic disease, it may be that a new philosophy of health regulation will enable us to undertake a similar journey, adapting the experience of success in tobacco to the control of other risk factors.

\section{References}

1. Fries JF. Aging, natural death and the compression of morbidity. $N$ Engl J Med 1980; 303(3): 130-5.

2. Research and Evaluation Committee, ed. Australia's National Tobacco Campaign, Evaluation Report. Volume 1 (1999). Canberra: Commonwealth Department of Health and Aged Care; 1999. Available from: http://www.quitnow.info.au/ internet/quitnow/publishing.nsf/content/evaluation-reports (Cited 3 November 2008.)

3. Ranson MK, Jha P, Chaloupka FJ, Nguyen SN. Global and regional estimates of the effectiveness and cosy-effectiveness of price increases and other tobacco control policies. Nicotine Tob Res 2002; 4(3): 311-9. doi:10.1080/14622200210141000

4. Protecting Children from Tobacco. A NSW Government Discussion Paper on the Next Steps to Reduce

Tobacco-Related Harm. North Sydney: NSW Department of Health; 2008. Available at: http://www.health.nsw.gov.au/pubs/ 
2008/pdf/protecting_children_from_tobacco.pdf (Cited 22 July 2008.)

5. Burns DM, Dybing E, Gray N, Hecht S, Anderson C, Sanner T et al. Mandated lowering of toxicants in cigarette smoke: a description of the World Health Organization TobReg proposal. Tob Control 2008; 17(2): 132-41. doi:10.1136/tc.2007.024158

6. Kozlowski LZ. The proposed tobacco regulation: the triumph of hope over experience? Tob Control 2008; 17(2): 132-41. doi:10.1136/tc.2008.025155

7. Stiglitz J. Pareto Efficient and Optimal Taxation and the New Welfare Economics. From Handbook of Public Economics. Auerbach AA, Feldstein M, editors. Amsterdam: Elsevier Science Publishers B.V.; 1987: pp. 991-1042.
8. Penman AG. Regulating combustible tobacco products when every cigarette is doing you damage. 13th World Conference on Tobacco OR Health, Washington 12-15 July 2006. Available from: http://2006.confex.com/uicc/wctoh/ techprogram/P6321.HTM (Cited 9 September 2008.)

9. Edwards C, Harris W, Cook D, Bedford K, Zuo Y. Out of the Smokescreen: does an anti-smoking advertisement affect young women's perception of smoking in movies and their intention to smoke? Tob Control 2004; 13(3): 277-82. doi:10.1136/tc.2003.005280

10. Feintuck M. The public interest in regulation. Oxford: Oxford University Press; 2004. 


\section{Regulation of research through research governance: within and beyond NSW Health}

\author{
Geoffrey S. Bloom ${ }^{\mathrm{A}, \mathrm{C}}$ and Deborah Frew ${ }^{\mathrm{B}}$ \\ ${ }^{\mathrm{A}}$ Geoffrey Bloom \& Associates, Sydney \\ ${ }^{B}$ Policy Impact Program, Sax Institute, Sydney \\ ${ }^{\mathrm{C}}$ Corresponding author.Email: gbloom@gbloom.com.au
}

\begin{abstract}
Research governance takes a broad approach to the regulation of human research encompassing: (a) frameworks and systems over ad hoc policy making; (b) quality standards as well as regulatory requirements; and (c) definition of roles and responsibilities of all parties involved in research. The effective and consistent implementation of research governance plays a role in the promotion of quality research. NSW Health has recently issued several policies and procedures in relation to research governance. However, for regimes of research governance to achieve optimal effectiveness, they must be consistent with each other in both the public and private sectors and across Australian jurisdictions.
\end{abstract}

Research involving human participants is regulated in many ways and at many levels. Regulatory requirements apply through Commonwealth and state legislation, and deal with a range of matters such as the rules governing the conduct of clinical trials for therapeutic goods, radiation safety, use of human tissue samples and privacy of personal health information. ${ }^{1-7}$ However, in addition to this legislative regulation of research, a relatively new concept of research governance has been developed. Research governance is a wider concept than regulation as it is directed to organisational frameworks and quality standards rather than mere mandates and prohibitions. In this article, we aim to:

- explain the meaning of research governance and its importance

- describe recent developments in research governance within NSW Health

- present arguments as to why consistent research governance frameworks across Australia are desirable for the promotion of research.

\section{Research governance and its importance}

Research governance has been described as an organisational framework through which all research meets appropriate standards of quality, safety, privacy, risk management, financial management and ethical acceptability and where the roles, responsibilities and accountabilities of all those who play a part in research are specified. ${ }^{8}$ This definition is similar to those used elsewhere in Australian and United Kingdom (UK) guidelines and in the literature. ${ }^{9-11}$ This definition highlights three important concepts in research governance:

- frameworks and systems over ad hoc policy making

- quality standards and practices as well as regulatory requirements

- the definition of roles and responsibilities for all parties involved in research.

Implicit in these three points is the concept of consistency as an important element to be considered in the implementation of research governance frameworks in Australia.

\section{Frameworks and systems}

The concept of frameworks and systems is core to instigating a transparent and accountable approach to research governance. In the past, many research institutions dealt with the governance of research in an ad hoc manner. This is unsurprising, given that there were few high-level policies that either delineated appropriate research governance standards or required them to be imbedded in the practice of institutions or health systems. Although there are existing effective instruments in relation to certain aspects of research governance (e.g. the National Statement on Ethical Conduct in Human Research), there has been a lack of policy, or at least of transparency, in relation to other aspects of governance. ${ }^{9}$

\section{Standards and practices}

The concept of standards and practices is important, because it underpins the quality of research that is produced. Meeting regulatory requirements is clearly a necessary part of good research but, in itself, is not sufficient. Regulations can mandate or prohibit the undertaking of certain actions or require the establishment of certain review mechanisms. However, the achievement of high standards of quality and safety requires flexible instruments against which performance can be assessed and improved. It requires the application of expert opinion, judgement and peer assessment, rather than just a measurement of compliance or non-compliance. 


\section{Roles and responsibilities}

The concept of defining the roles and responsibilities of all parties is of crucial importance, as it recognises that all participants - including governments, health systems, institutions, various review bodies and researchers - have a role to play in ensuring high quality, safe and ethical research. In the past, there has been a tendency to conflate research governance and ethical review of research, so that some Human Research Ethics Committees (HRECs) have been required to play the role of both ethical reviewer and institutional gatekeeper. The proper implementation of research governance recognises that health systems, institutions and researchers all have roles in relation to the proper conduct of research and that it improves the ability of each player to fulfil their responsibilities efficiently and effectively if their roles are clearly defined.

\section{Consistency}

The question of what is meant by consistency in research governance is one that bears examination. There are many different types of research, governed by various legislation, guidelines, codes of practice and accepted standards. The requirements in relation to governance of clinical trials, for example, will be different to those for population health research. We do not suggest that these different types of research in different settings should be governed in exactly the same manner. What we do advocate is a basic set of underlying requirements that are consistent across institutions and jurisdictions in order that the following may occur:

1. there is a level of public accountability in ensuring that all factors relevant to the governance of a research project have been examined by an appropriate authority, regardless of where the research takes place

2. researchers are able to approach different institutions for approval of their research with the same, or a similar set of, information regarding their project, as opposed to producing a new set of information for each institution

3. the various stakeholders in the research endeavourincluding institutions, researchers and HRECs - are clear as to the role they play in relation to the governance of research, and that these roles are defined at a system level, not at the individual committee or institutional level.

\section{Research governance developments within NSW Health}

Most human research undertaken in Australia is conducted in hospitals, their associated universities and research institutes, many of which are public institutions. As New South Wales (NSW) is Australia's most populous state with the largest public hospital system, NSW Health policies are likely to apply to a significant proportion of all human research in Australia. ${ }^{11}$ In the past five years or more, NSW Health and other state government authorities have developed policies that have given organisational shape and substance to the concept of research governance. It is important for those involved in research within NSW Health to understand the policies that comprise the new research governance framework in this state.

\section{Frameworks and systems}

NSW Health has developed standard operating procedures for its HRECs. ${ }^{12}$ The standard operating procedures cover: objectives; functions; scope of responsibility; status of the HREC within the area health service; accountability of the HREC; membership; conduct; post-approval responsibilities and activities; and complaints and review. The aim of these policies is to save individual HRECs from establishing their own operational parameters, thereby allowing them to spend more time and resources on their core business of ethical review. These standard operating procedures also aim to enhance consistency of HREC operations across NSW Health.

NSW Health's recent policy and procedures to provide for single ethical and scientific review of multi-centre research aim to reduce duplication of HREC effort and make more efficient use of scientific and ethical expertise, and also to save time for proponents of research. ${ }^{13,14}$ The ethical review of research will be conducted by an accredited lead HREC and this single approval will serve as a sufficient ethical approval for the proposed research at any site within NSW Health.

The line between quality improvement and research can sometimes be difficult to draw. In either case, the activity may raise ethical issues beyond those occasioned by direct patient care. The relevant NSW Health guideline, which elaborates upon the national standard, aims to assist in determining whether a quality improvement exercise raises ethical risks to participants requiring review by an HREC. ${ }^{15,16}$

\section{Standards and practices}

The quality of the operations of NSW Health lead HRECs is now determined by accreditation standards. ${ }^{13,14}$ Each lead HREC is accredited in a specific type of research; for example, clinical trials or epidemiological research. Among other things, the accreditation standards provide for lead HRECs to be registered with the National Health and Medical Research Council (NHMRC), to meet NHMRC minimum membership requirements in terms of number of members and requisite expertise, to have sufficient resources and executive support, and to meet a maximum 60 day turnaround for research applications.

For research to be ethical it must be of sufficient scientific quality. NSW Health policy seeks to support standards of scientific review of clinical drug trials, including providing 
for review by a body other than the reviewing HREC, where scientific issues are beyond that HREC's expertise. ${ }^{17}$ The aim of this policy is to assist HRECs to comply with legal and administrative requirements under the Clinical Trial Exemption (CTX) and the Clinical Trial Notification (CTN) Schemes of the Therapeutic Goods Administration.

Clinical trial agreements are now generally standardised, with all commercially sponsored research conducted within NSW Health being considered in accordance with the Medicines Australia standard form clinical trial agreement, developed jointly by Medicines Australia, the Victorian Managed Insurance Authority and NSW Health, and in consultation with other Australian health departments. ${ }^{18}$ A similar agreement will be released to govern trials sponsored by contract research organisations and collaborative trial groups.

\section{Roles and responsibilities}

A major change aimed at shifting the governance burden associated with research away from HRECs is the advent of a policy requiring each research site or institution to consider and approve the operational dimensions of having research conducted within its facilities. ${ }^{19}$ A research governance officer, reporting to the institution rather than the HREC, is responsible for considering whether the use of the institution's resources (such as facilities, staff and equipment) is appropriate, whether the project adheres to the institution's site-specific policies (such as sign-offs from appropriate heads of department) and whether the institutionally based researchers involved in the project have the relevant training, expertise and experience. Research within an area health service may only begin once it has scientific and ethical approval by a duly constituted HREC and operational approval for each specific site within the area health service and the Chief Executive of the area health service, or delegate, has agreed to the commencement of the research.

Given that entities other than NSW Health are responsible for initiating and sometimes conducting research within NSW Health, it is necessary to define the roles and responsibilities applicable to insurance and indemnity for research. At the time of writing, NSW Health has released a draft policy for area health services to assist them with this crucial aspect of risk management and to standardise requirements throughout NSW Health. ${ }^{20}$

\section{Expanded horizons for research governance}

We have argued that research governance plays a role in promoting higher quality human research; has the potential to streamline the research approval process; and ensures that the main stakeholders in the research endeavour are vested with appropriate responsibilities. The NSW Health framework described above is but one example of a research governance system that could apply within
Australia. At present, it relates only to the NSW public health system and not to the private sector, the university sector or other Australian jurisdictions. Other Australian states and institutions have also implemented governance frameworks for human research. As yet, it is not possible to tell which of the (aspects of) various frameworks will prove superior. All other things being equal, it is likely that consistency in research governance across research settings will improve the effectiveness of research governance in any one setting. We advocate that this level of consistency should be national, for the following reason.

A great deal of research in Australia is undertaken on a national, multicentre basis. ${ }^{21,22}$ That is, it is conducted in multiple sites within different jurisdictions and across the public and private sectors. We have argued that consistency (as we have defined it) is important to achieving the aims of research governance. In the context of multicentre research, it is reasonable to expect that this consistency is best found at a national level. By extension, and given that much research in Australia is part of larger research projects spanning several countries, it is also desirable to seek to achieve consistency with the larger centres of research beyond Australia.

Australia has often been described as a good place to do research. ${ }^{21,23,24}$ Although this is undoubtedly the case, there are several factors that mitigate against Australia's ability to compete with other countries in maintaining and further developing a strong, vibrant and innovative research culture. Many of these factors are out of our control, such as geographic isolation, shortage of human research subjects and growth in study costs in comparison to other Asia-Pacific and emerging European nations. ${ }^{22}$ However, the regulatory and governance environment is amenable to control and can play a significant role in Australian and international decisions as to where to conduct research, particularly in relation to clinical trials. ${ }^{21,22}$

The NHMRC is currently engaged in a project to streamline ethical review of multicentre research nationally. ${ }^{25}$ This project is an example of the approach we advocate: ethical review of multicentre research is one part of research governance and the multicentre nature of this project implies the desirability of consistency in research governance across centres. It remains to be seen which (parts) of the developing regimes of research governance in Australia will prove most effective, including the regime within NSW Health. In our view, the degree to which one regime is consistent with others is, in itself, a significant element is its effectiveness.

\section{Conclusion}

The implementation of research governance frameworks is a valuable development in promoting high quality, safe and ethical research. Such a research governance framework 
is being developed within NSW Health. However, a national approach to research governance is desirable, and its value is likely to be enhanced if the approach is as consistent as possible across jurisdictions, institutions and public and private sectors.

Disclosure: Deborah Frew was Director, Health Research and Ethics Branch, NSW Department of Health at the time the policies discussed in this article were developed and played a substantial role in their content.

Geoffrey Bloom has provided legal and policy advice to the Health Research and Ethics Branch, on issues of research governance.

\section{References}

1. Therapeutic Goods Act 1989 (Cth).

2. Therapeutic Goods Regulation 1990 (Cth).

3. Radiation Control Act 1990 (NSW).

4. Radiation Control Regulation 2003 (NSW).

5. Human Tissue Act 1983 (NSW).

6. Health Records and Information Privacy Act 2002 (NSW).

7. Privacy Act 1988 (Cth).

8. National Health and Medical Research Council, Australian Research Council, Universities Australia. Australian code for the responsible conduct of research. Revision of the joint NHMRC/AVCC statement and guidelines on research practice. Canberra: Australian Government; 2007. Available from: http://www.nhmrc.gov.au/publications/synopses/r39syn.htm (Cited 17 July 2008.)

9. Australian Government (NHMRC, ARC), Australian Vice-Chancellors' Committee. National statement on ethical conduct in human research. Canberra: Australian Government; 2007. Available from: http://www.nhmrc.gov.au/publications/ synopses/e72syn.htm (Cited 17 July 2008.)

10. UK Department of Health, Social Services and Public Safety. Research governance framework for health and social care, 3rd edn. Belfast: Department of Health, Social Services \& Public Safety; 2005. Available from: http://www.centralservices agency.com/files/rdo_whats_new/file/RGF_061106.pdf (Cited 17 October 2008.)

11. Walsh MK, McNeil JJ, Breen KJ. Improving the governance of health research. Med J Aust 2005; 182(9): 468-71.

12. NSW Health. Human research ethics committees: operations manual for NSW Health HRECs, GL2005_059. North Sydney: NSW Health; 2005. Available from: http://www.health. nsw.gov.au/policies/gl/2005/GL2005_059.html (Cited 17 July 2008.)

13. NSW Health. Model for single ethical \& scientific review of multi-centre research, PD 2007_072. North Sydney: NSW Health; 2007. Available from: http://www.health.nsw.gov.au/ policies/pd/2007/PD2007_072.html (Cited 17 July 2008.)
14. NSW Health. Human research ethics committees: national ethics application form - application within NSW Health, PD2007_026. North Sydney: NSW Health; 2007. Available from: http://www.health.nsw.gov.au/policies/pd/2007/ PD2007_026.html (Cited 17 July 2008.)

15. NSW Health. Human research ethics committees - quality improvement \& ethical review: a practice guide for NSW, GL2007_020. North Sydney: NSW Health; 2007. Available from: http://www.health.nsw.gov.au/policies/g1/2007/ GL2007_020.html (Cited 17 July 2008.)

16. NHMRC. When does quality assurance in health care require independent ethical review - Advice to Institutions, Human Research Ethics Committees and Health Professionals. North Canberra: Commonwealth of Australia; 2003. Available from: http://www.nhmrc.gov.au/health_ethics/human/conduct/ guidelines/_files/e46.pdf (Cited 17 July 2008.)

17. NSW Health. Human research ethics committees: standards for scientific review of clinical trials, PD2007_035. North Sydney: NSW Health; 2007. Available from: http://www.health.nsw. gov.au/policies/pd/2007/PD2007_035.html (Cited 17 July 2008.)

18. NSW Health. Clinical research: standard clinical trial research agreement for NSW public health organisations - NSW Department of Health, PD2007_038. North Sydney: NSW Health; 2008. Available from: http:/www.health.nsw.gov.au/ policies/pd/2008/PD2008_039.html (Cited 17 July 2008.)

19. NSW Health. Research - Authorisation of proposals to conduct research on humans [Includes the Site Specific Assessment (SSA) Form \& Guidance document for completing the SSA Form], PD2007_043. North Sydney: NSW Health; 2007. Available from: http://www.health.nsw.gov.au/ policies/pd/2007/PD2007_043.html (Cited 17 July 2008.)

20. NSW Health. Clinical trials: risk management, insurance and indemnity, draft policy directive (for consultation). North Sydney: NSW Health; 2005.

21. Woolley K, Woolley M. Clinical trials in Australia-the FACTS. Good Clin Prac J 2003; 10(5): 13-6.

22. The Allen Consulting Group. Drivers of pharmaceutical industry investment; understanding Australia's competitive position. Available from: http:/www.medicinesaustralia.com.au/ pages/images/Drivers\%20of\%20Pharmaeceutical\%20Industry \%20Investment\%20FINAL20060915.pdf (Cited 17 July 2008.)

23. Mudge SJ. Australia: The number one place for clinical trials? App Clin Trials 2006; 15(9): 44-51.

24. The Economist Intelligence Unit. Benchmarking Study of the Australian and International Pharmaecuticals Industries. Canberra: Australian Government Department of Industry, Tourism and Resources; 2005. Available from: http://www.innovation.gov.au/General/Innov-PS/Documents/ Pharma_Benchmarking_Final_Sept20051007095438.pdf (Cited 17 July 2008.)

25. Australian Government, National Health and Medical Research Council. Harmonisation of Multi-centre Ethical Review (HoMER). Canberra: Australian Government; 2008. Available from: http://www.nhmrc.gov.au/health_ethics/ hrecs/homer.htm (Cited 22 October 2008.) 


\section{Ensuring safe drinking water in regional NSW: the role of regulation}

\author{
Paul M. Byleveld ${ }^{\mathrm{A}, \mathrm{D}}$, Michelle A. Cretikos ${ }^{\mathrm{B}, \mathrm{C}}$, \\ Sandy D. Leask ${ }^{\mathrm{A}}$ and David N. Durrheim ${ }^{\mathrm{C}}$ \\ A Water Unit, NSW Department of Health \\ ${ }^{\mathrm{B}}$ NSW Public Health Officer Training Program, NSW Department \\ of Health \\ ${ }^{\mathrm{C}}$ Hunter New England Population Health, Hunter New England \\ Area Health Service \\ DCorresponding author. Email: paul.byleveld@doh.health.nsw.gov.au
}

acute outbreaks of waterborne gastrointestinal disease. Illness related to unsafe drinking water can lead to substantial morbidity and mortality, community anger and detrimental economic impacts. ${ }^{1,2}$

NSW Health exercises its responsibility as the public health regulator of metropolitan water utilities (Sydney Water Corporation, Sydney Catchment Authority and Hunter Water Corporation) through operating licences and memoranda of understanding. In regional and rural areas of NSW, drinking water is provided by 107 local water utilities, mostly councils, serving a population of 1.7 million and operating 323 public water supply systems. NSW Health provides public health oversight of these regional water utilities through the NSW Health Drinking Water Monitoring Program. ${ }^{3}$ The Drinking Water Monitoring Program provides guidance on drinking water monitoring as well as on implementing several elements of the Australian Drinking Water Guidelines. ${ }^{4}$ This paper describes the Program and its regulatory context and reviews the impact of the Program on microbial drinking water quality.

\section{The Australian Drinking Water Guidelines}

The Australian Drinking Water Guidelines published by the National Health and Medical Research Council serve as the model of best practice in NSW. ${ }^{4}$ These guidelines provide a risk management framework for drinking water supply systems, which includes a multiple barrier 'catchment to tap' approach, because a single barrier risk management approach is vulnerable to failure. ${ }^{5}$ The Guidelines recommend that systems should be monitored for drinking water quality and operational compliance. ${ }^{4}$

The Guidelines provide guideline values for microbial, physical, chemical and radiological characteristics that affect health or the quality of drinking water, and recommend that drinking water supplies be monitored regularly for Escherichia coli, which is an indicator of faecal contamination.

Although monitoring is an important step in verifying that preventive measures are working effectively, the current monitoring system for NSW regional water supplies has a number of inherent limitations, including:

- sampling cannot detect all contamination events

- exposure of the supply population to contaminated water may occur days before a non-compliant sampling result is available
Safe drinking water is essential for public health. Drinking water can pose serious health risks through microbial and chemical contamination, or inadequate disinfection and treatment. ${ }^{1,2}$ In particular, microbial contamination poses an ongoing threat of sporadic gastrointestinal illness and 
- the system may fail to identify contamination with certain pathogens (e.g. protozoa or viruses) unless the contamination is accompanied by the indicator organism (E. coli) or elevated turbidity.

Thus the current system of microbial and chemical monitoring of regional water supplies is unable to provide routine early warning of contamination events. For water utilities to supply drinking water that is safe, as defined in the Guidelines, NSW Health strongly recommends that water utilities implement the Guideline's Framework for Management of Drinking Water Quality.

\section{The legislative basis for ensuring drinking water safety}

In 1998, Sydney's drinking water was found to contain Cryptosporidium and Giardia, which resulted in a series of alerts to boil water affecting more than three million consumers over a two-month period. Following this event, the Public Health Act 1991 was amended to ensure that NSW Health had adequate powers in relation to drinking water quality. ${ }^{6,7}$ The amendments gave NSW Health the powers to:

- require a water utility to issue advice to the public regarding the safety of drinking water (e.g. a boil water alert)

- correct misleading information issued by a water utility

- enter and inspect water utility premises

- require the testing of drinking water

- require the production of information (e.g. the results of water testing)

- close a water supply or order that it be brought to a condition that no longer poses a risk to public health.

In contrast to the operating licence requirements for metropolitan water utilities, there is no requirement for regional water utilities to fully implement the Australian Drinking Water Guidelines (and its framework).

\section{How does NSW Health exercise its legislative responsibility?}

The current NSW Health Drinking Water Monitoring Program has been operating comprehensively since 2001 . Samples are allocated annually to each public water supply system and tested by NSW Health (or other accredited) laboratories free of charge. Characteristics routinely tested include microbial (E. coli, total coliforms and corresponding field results, including chlorine) and physical/ inorganic chemical (more than 30 characteristics). Characteristics tested through project monitoring include bacterial pathogens, pesticides and disinfection by-products (more than 150 characteristics). Microbial and physical/ chemical monitoring results are stored in the internetbased NSW Drinking Water Database, which allows secure access to results for local water utilities, NSW Health and other government agencies. ${ }^{8}$ The Database records results for more than 20000 samples per year from 323 water supply systems. The Database has a user-friendly web interface that allows water utilities and public health units to search for results, generate reports and download data files (Figure 1). The reports provide basic descriptive statistics for each characteristic, including the number of samples tested and the percentage of samples meeting guideline values.

The NSW Health Drinking Water Monitoring Program meets the recommendations of the World Health Organization by providing public health oversight of drinking water supplies, using predominantly independent testing and consolidating data as an input to the development of public health policies. ${ }^{9}$

The Program recommends the minimum numbers of samples that should be taken based on the size and complexity of water supply systems and in accordance with the Guidelines. This allocated number of samples must be collected to ensure that water quality remains satisfactory. The Program provides water utilities with protocols for responding to incidents of contamination (both microbial and chemical) or treatment system interruption. The Program also defines the roles of the NSW Department of Health Water Unit, local public health units and the local water utility in responding to such incidents.

Significant factors in the acceptance of the current Program include its development in consultation with, and support by, the peak industry bodies, including Local Government and Shires Associations and the NSW Water Directorate.

\section{Functioning of the NSW Health Drinking Water Monitoring Program}

The current Program commenced in late 2000, with data captured from 2001. The Water Unit and local public health units are active in promoting the Program to local water utilities. Multiple methods of communication are used to ensure the widest possible understanding of the Program within water utilities.

Each year, the Water Unit writes to the water utility general managers to advise them of sampling frequency recommendations. Sample testing is provided free of charge by NSW Health laboratories. The Water Unit issues bar-coded labels that uniquely identify each sample collected under the Program and remove the need for sample submission forms, previously completed by water utilities. NSW Health also actively promotes the Program through industry conferences, newsletters and regional training workshops for local water utilities. The Department of Water and Energy (DWE) has supported and promoted the Program through their Best-Practice Management of Water Supply and Sewerage Guidelines and training courses for water treatment plant operators. 


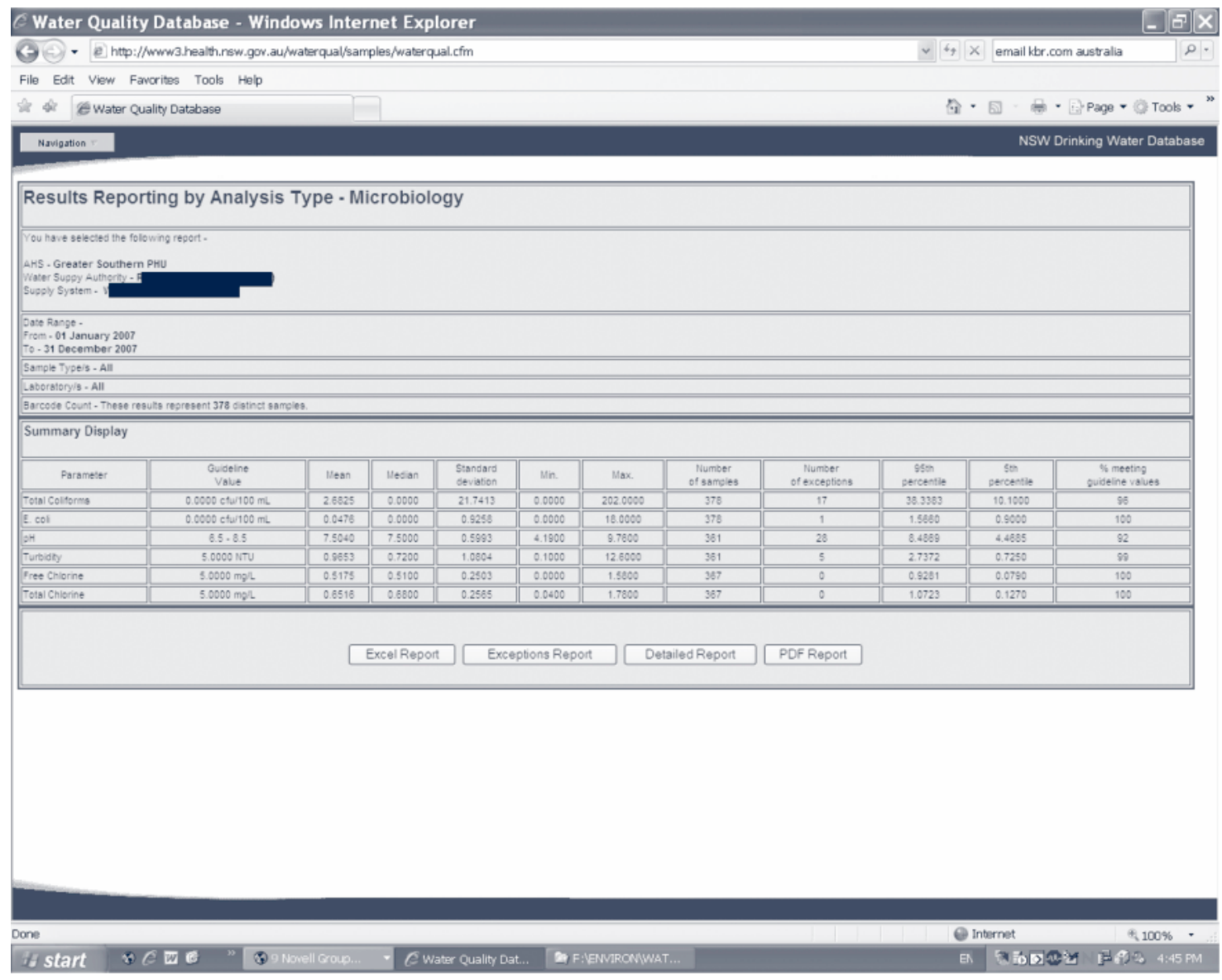

Figure 1. A screen view of the NSW Drinking Water Database.

NSW Health and the DWE actively encourage water utilities to adopt the Framework as a model for managing their supplies. However, it is unlikely that all regional water utilities will fully implement the Framework unless it becomes a regulatory requirement.

Some water utilities use the Database results to prepare reports for local communities. The Database also allows NSW Health to monitor the adequacy of sampling and reporting by each utility. Reminders are issued to utilities to increase sampling frequency where needed.

NSW Health laboratories report non-compliant results to the water utility and public health unit. This provides public health units with an opportunity to confirm that the response protocols are being followed, including investigation and immediate corrective action by the local water utility.

\section{The impact of the NSW Health Drinking Water Monitoring Program}

The current Program has helped improve the management of regional and rural water supplies. Prior to its introduction, $10 \%$ of microbial samples were reported to be noncompliant, and $27 \%$ of water supply systems failed to submit samples. ${ }^{10}$
Since the introduction of the current Program, there has been a significant improvement in both microbial compliance (Figure 2) and adequacy of microbial sampling (Figure 3) in regional NSW. The significance of improvement was assessed using the Cochran-Armitage test for trend in compliance by year. In 2007, the overall results of microbial sampling achieved the Australian Drinking Water Guidelines 2004 criteria, i.e. no more than two samples per 100 samples were non-compliant for $E$. coli (Figure 2). This improvement appears to be the result of many factors, including improved reporting to the NSW Health Drinking Water Monitoring Program, monitoring and maintenance of regional drinking water systems, disinfection and treatment of drinking water supplies, and sampling frequency. It is possible that in some systems there are sampling biases that result in unusually high compliance. Despite the improvements in regional microbial performance, some small water supply systems remained well below the targets for sampling frequency and water quality. In order to better detect systematic problems, repeat testing and follow up occurs with water utilities that have non-compliant samples, especially with those that exceed the $2 \%$ target.

The NSW Health Drinking Water Monitoring Program and the Database has been well accepted by local water utilities 


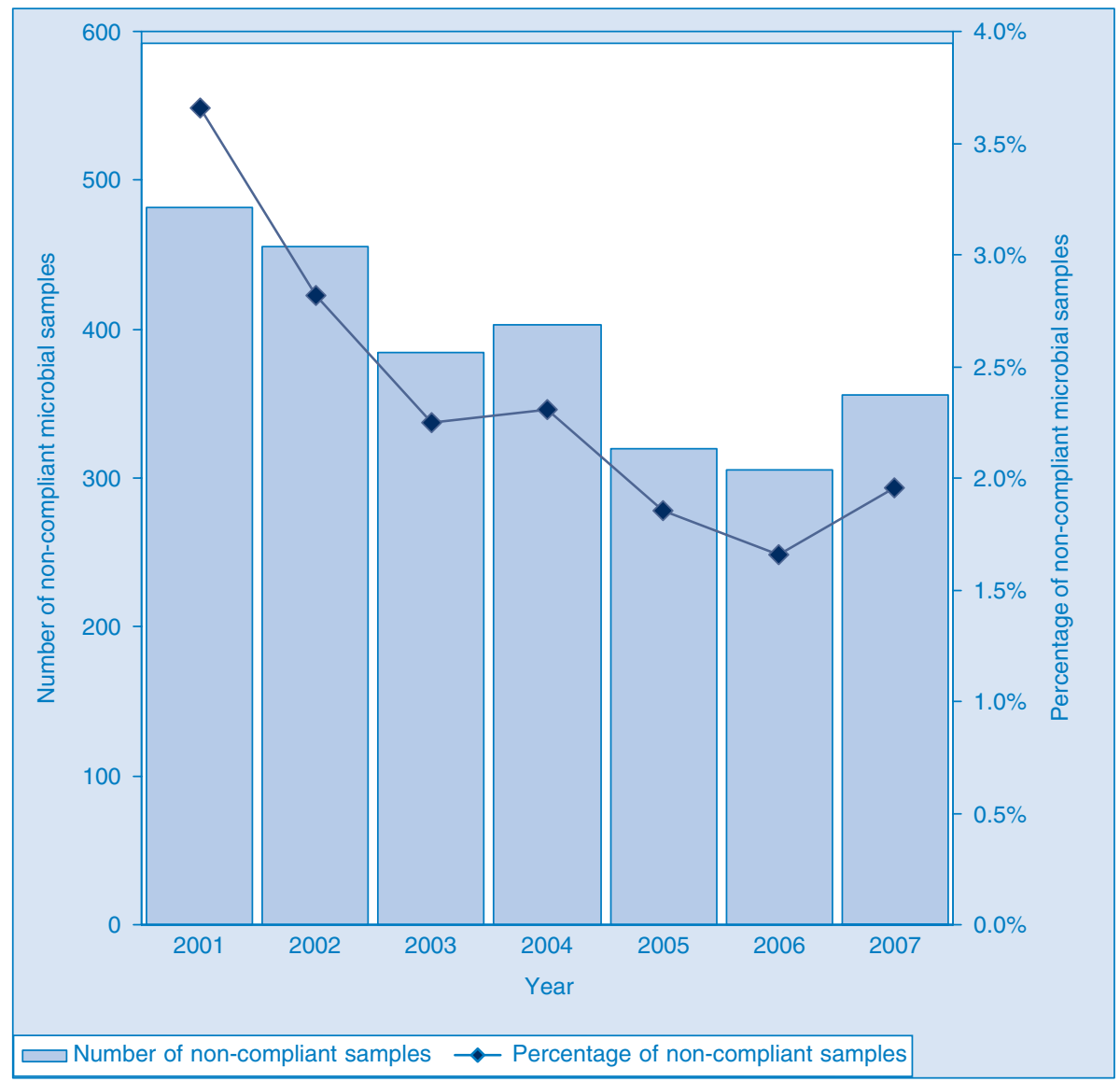

Figure 2. Trend in microbial compliance in regional NSW by year (2001-2007), samples tested for Escherichia coli. $p$ value $<0.001$ for trend test (Cochran-Armitage test). Source: NSW Drinking Water Database.

and government agencies. Since the amendment of the Public Health Act in 1998, NSW Health has not used legislative powers to place orders on public water utilities. In contrast, over the same period, orders have been placed on two private water supplies that represented a risk to public health and did not comply with NSW Health advice.

The powers would be used in relation to water utilities should it be necessary. To make such decisions, public health units have access to the Database and disease surveillance data. In cases where a water utility does not meet sampling requirements, public health units follow up and remind the water utility of the requirements and the powers that exist under the Public Health Act. Where a persistent risk to public health is identified, the public health unit will advise the water utility to issue an alert to boil water or other warnings to the community. In most cases, water utilities willingly issue alerts to boil water, often before public health unit intervention.

During 2007, there were 12 such alerts issued in regional NSW. Two of these alerts were instituted before test results became available, and were the result of contaminated raw water or treatment failure. The remainder were issued following the detection of $E$. coli in routine drinking water samples. In such cases, the community may already have been exposed by the time a boil water alert is issued. Complete implementation of the Guideline's Framework for Management of Drinking Water Quality by all water utilities is the only way to ensure safe drinking water for regional communities.

\section{Conclusion}

The NSW Health Drinking Water Monitoring Program has contributed to a marked improvement in the monitoring and quality of drinking water in regional NSW. This has been achieved through a combination of factors, including: a clear regulatory framework; a centralised system of ongoing sampling monitoring; technical support for local utilities and public health units; and collaborative relationships between public health units and local water utilities. Despite these improvements, more work is needed to support smaller water supply systems to meet the Australian Drinking Water Guidelines requirements and ensure safe drinking water for their communities. 


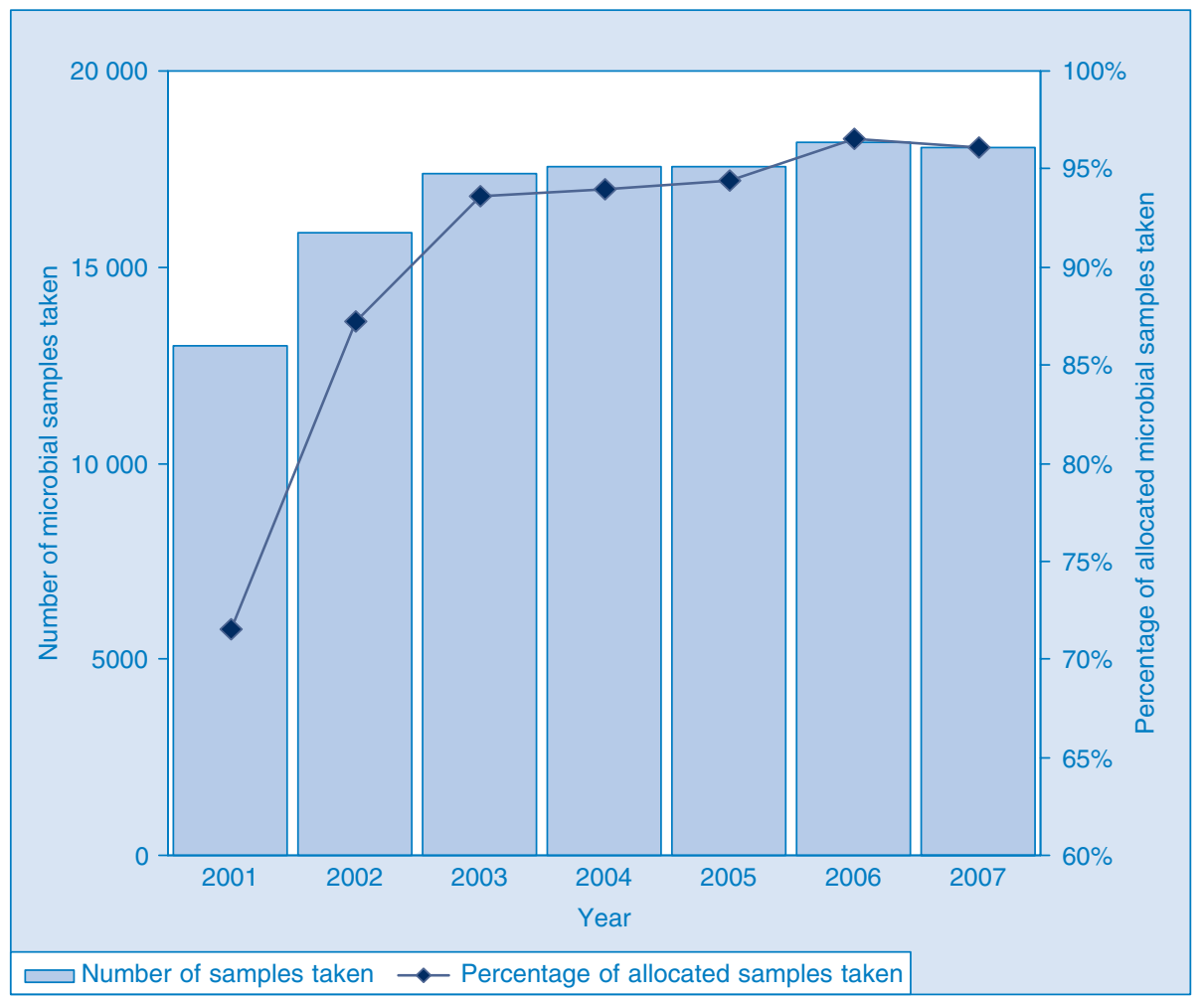

Figure 3. Trend in microbial sampling adequacy in regional NSW by year (2001-2007), using samples tested for either Escherichia coli or thermotolerant coliforms. p value $<0.001$ for trend test (Cochran-Armitage test). Source: NSW Drinking Water Database.

The NSW Drinking Water Database has helped identify persistent and sporadic problems in water supplies. It has also provided useful historical data to inform decision making on improvements required for specific supplies. Access to this data has proven useful in advocating for upgrades to water treatment, prioritising expenditure under the Country Towns Water Supply and Sewerage Program, and informing government inquiries.

The most significant challenge for the future is to ensure that all water utilities fully implement the Australian Drinking Water Guidelines Framework. Communities cannot simply rely on end-point drinking water quality monitoring to prevent outbreaks. There is strong international consensus that a preventive risk-management approach as set out in the Framework is the most reliable way to protect public health.

\section{Acknowledgment}

Thanks to Ling Li for preparing the figures.

\section{References}

1. Hrudey SE, Hrudey EJ. Safe drinking water: lessons from recent outbreaks in affluent nations. London, UK: International Water Association Publishing; 2004.

2. Hunter PR, Waite M, Ronchi E, eds. Drinking water and infectious disease: Establishing the links. Boca Raton, Florida: CRC Press/IWA Publishing; 2003.
3. NSW Health. Drinking Water Monitoring Program December 2005. NSW Department of Health; 2008.

4. National Health and Medical Research Council and Natural Resource Management Ministerial Council. Australian Drinking Water Guidelines. Canberra: NHMRC; 2004.

5. Reason J. Managing the risk of organisational accidents. Aldershot, UK: Ashgate; 1997.

6. McClellan P. Sydney Water Inquiry - Final Report Volumes 1 and 2. Sydney: New South Wales Premier's Department; 1998.

7. NSW Public Health Act 1991 No 10.

8. Persson L, Byleveld P, Fien M, Cowie C. NSW Drinking Water Database. Perth: OzWater Australian Water Association National Convention, April 2003, pp. 60-1.

9. World Health Organization. Guidelines for drinking-water quality [electronic resource]: incorporating first addendum. Vol. 1, Recommendations, 3rd ed. Geneva: WHO; 2006. Available at: http://www.who.int/water_sanitation_health/dwq/gdwq3rev/en/ (Cited 23 October 2008.)

10. Cowie C, Corbett S. Surveillance of rural drinking water quality in NSW. N S W Public Health Bull 1994; 5: 35-9. doi:10.1071/NB94016 


\section{Enforcing law on tobacco sales to minors: getting the question and action right}

\section{Douglas C. Tutt}

Health Promotion, Northern Sydney Central Coast Area Health Service

Email:dtutt@nsccahs.health.nsw.gov.au

\begin{abstract}
There is a substantial history of healthrelated law in Australia, but only recently has this included a significant amount of state regulation pertaining to tobacco promotion, sale and public use. The important question is: under what circumstances do regulation and law enforcement work? Rigorous, energetic, long-term local law enforcement on the supply of tobacco to minors demonstrates success in preventing uptake. A model for success combines education, enforcement and publicity; a model used to some effect in alcohol law. Future directions in regulation might include on-the-spot penalties; ensuring the law is simple and has community support; striving for sufficient resources, enthusiasm and skills; and making the tobacco retail industry pay some of the costs of regulating that industry.
\end{abstract}

Bringing law to bear for public health ends is not new. The first Public Health Act was passed in Britain in 1848, with an independent New South Wales (NSW) Act in 1896. Other NSW laws, like the Abattoir Act of 1850 and the Infectious Diseases Supervision Act of 1881, were necessary to improve health standards. ${ }^{1}$

Only comparatively recently has law played a significant part in combating tobacco harm with Section 59 of the Public Health Act 1991 of NSW, making sales to under-18year-olds illegal, although it had been officially illegal to sell to under-16-year-olds for nearly a century. ${ }^{2}$ Restrictions on marketing and advertising, and on smoking in enclosed public places have become state law since then. ${ }^{2,3}$

Divergent opinions about the effectiveness of restrictions on selling tobacco to juveniles have been expressed. One view is that it does not reduce teen smoking while proponents counter that ineffective enforcement efforts do not hinder youth-purchasing behaviour, and therefore could not be expected to reduce tobacco consumption. ${ }^{4-7}$

\section{An example of effective law enforcement}

The Gosford-based health promotion unit of Northern Sydney Central Coast Area Health Service has undertaken vigorous activity on cutting retail supply to minors since 1994 when intense education of retailers started. Initially, the enforcement component of this program was undertaken with local police co-operation, but the compliance testing methodology of under-age volunteers attempting purchases has become part of NSW Health practice across the state and public health units now undertake most of the enforcement and prosecution activities. ${ }^{8}$

Volunteers aged 14-16 years in everyday clothing were rehearsed in asking for a particular product and instructed to be honest if asked by retailers about their age or identification during these controlled purchase operations. Successful prosecutions were the subject of concentrated media activity, including local newspaper front pages and editorials, television current affairs programs' hidden cameras and an advertised hotline for the public to report law-breaking retailers. Most states were undertaking similar programs by $2000 .^{9}$

The random testing methodology was confirmed as appropriate in the NSW Court of Criminal Appeal and the Court of Appeal. ${ }^{10,11}$

The effect on retailer behaviour was quick on the Central Coast (Gosford and Wyong Local Government Areas with a population in excess of 250000 ). Within 12 months of starting prosecutions in May 1995, the proportion of retailers selling fell from $30 \%$ (which occurred despite months of education) to $8 \%$ and continued to further decline throughout the 1990s. ${ }^{12}$ In 1995, there were six highly publicised, successful prosecutions in this area. The impact of those prosecutions was spread by extensive public relations, creating the perception of a high risk of detection. Ongoing publicity in media and by direct mail is a continuing feature of this work. Although some other health areas did commence action by 1996, none were yet successful in reducing the retailer-selling rate on test to less than $10 \%$, with results varying from 12 to $47 \% .^{13}$ 
Monthly smoking prevalence 1993 to 2005 for adolescents aged 12 to 17 years

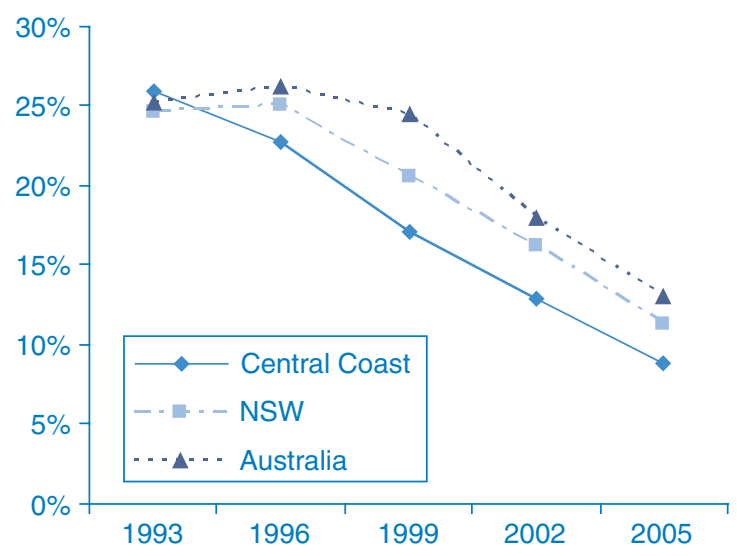

Figure 1. The monthly smoking prevalence rates for adolescents aged 12 to 17 years, Australia, NSW and Central Coast, 1993-2005. Source: Local data from Northern Sydney Central Coast Area Health Service's 2007 Performance Review; NSW and Australian rates are derived from references ${ }^{22-27}$ and unpublished data from the Australian Secondary School Students Surveys of 1993, 1996, 1999 calculated on the unweighted attained sample of those who smoked in the last 4 weeks.

No other special teen smoking intervention was under way during this time in this location. Ordinary school education or exposure to state or national media campaigns continued as usual. A number of local high schools periodically collected and provided data on smoking rates. The first effect was on the youngest and lightest smokers, but as time went on this effect spread across the 12-17 year age range. ${ }^{12}$ The adolescent smoking rate on the Central Coast in 1993 was similar to that of the rest of the state and nation; however, by 1996 the area had a significantly lower rate than the rest of NSW and, by 1999 , only $17.1 \%$ of local teens were smoking compared with $25.9 \% 6$ years earlier. $^{12}$

The methodology has continued in the same manner since 1999. The rates of monthly teen smoking compared with state and national rates are shown in Figure 1.

The results in Figure 1, which were presented in Northern Sydney Central Coast Area Health Service's 2007 Performance Review, show the continued difference in local rates from state and national rates. In 2002, eight years after starting action on supply to minors, the Central Coast teen smoking rate remained significantly lower $(\mathrm{p}<0.0001)$ than that of NSW and Australia, even though the reduction in teen smoking in those larger jurisdictions paralleled that of the Central Coast.

The reason is probably because nicotine is an addictive product. Intervention on supply over time becomes intervention in demand, as fewer young people start smoking in the first place. Fewer 13-year-old smokers at one time means fewer addicted 16-year-old tobacco consumers three years later. As time progresses, fewer continuing teen addicts mean fewer smokers can entice others to join them, so the effect continues to compound.

The area between the Central Coast line in Figure 1 and the Australian line represents the total of "prevented smokers' brought about by doing something different from the rest of the country. Of course, other interventions have occurred throughout the nation, notably on the supply side with taxation changes post 1999, and large scale media campaigns on the demand side. But the difference achieved by adopting energetic law enforcement early on is illustrated by Figure 1. That difference equates to nearly $20 \%$ fewer teen smokers in those 12 years on the Central Coast than if direct-supply-side law enforcement had not been undertaken when it was.

\section{Other examples of modern health law at work}

One of the best examples of saving lives with law in recent decades is roadside random breath testing for alcohol. A quarter of a century ago, more than $40 \%$ of deaths on NSW roads were attributed to alcohol. ${ }^{14}$ The death rate is now reduced to $23 \% .{ }^{15}$ Over 400 lives are saved every year in NSW as a result of the intervention. This outcome has come about by "strengthened legislation and enforcement in conjunction with high profile media and public education activities". ${ }^{16}$

Australia's problems with alcohol attract media and policy attention. Licensed premises are expected to exercise responsible service of alcohol. ${ }^{17}$ What method works to get these suppliers to practise this responsibility? Unfortunately, it seems education alone is not enough. Just educating bar staff to get them to do the right thing achieves fewer than one in ten acting correctly, but coupling that with enforcement improves that figure nearly eight-fold. ${ }^{18}$

\section{Determining success}

Success in achieving change in tobacco sales to minors, or in road safety and alcohol are underpinned by education, enforcement and publicity. Education is necessary, but it is not sufficient. Enforcement adds to effectiveness. Extensive publicity about enforcement increases the perceived risk of being caught, and also engages a concerned community in knowing that action to address a problem is underway. All of this activity has to be carried out with vigour and skill.

The question to be answered is not whether law and enforcement work. Rather the question is "under what circumstances do they work in achieving public health aims?" The examples above show that education, enforcement and publicity are key components in achieving success.

The Canadian Cancer Society, in reviewing the features of supply efforts targeting tobacco and minors, concluded that 
a decrease in smoking was brought about by programs that achieved very high rates of retailer compliance and involved comprehensive community-based interventions, well-drafted law, regular checks on compliance, meaningful penalties for offenders and strong community support. ${ }^{19}$ Such factors may underlie success in various fields of public health law. There is strong community support for action on tobacco, with nearly $90 \%$ of people supporting stricter laws and harsher penalties for selling to juveniles. ${ }^{20}$

The total count of prosecutions under any law can be related to a number of factors. Few prosecutions may indicate that nearly everyone abides by the law; but it could also mean that a law is difficult or complicated to interpret, or that there are few resources, or little enthusiasm or skill for prosecutions. Many of the offences committed around sales, possession or supply of alcohol are dealt with by Penalty Infringement Notices (on-the-spot fines), increasing the ease of prosecution. The implementation of Penalty Infringement Notices is an important possible future direction for tobacco law.

Another question that might arise is whether scarce resources would be better spent in other ways. Estimating staff time and goods and services expenditure invested through the 1990s in all the activities associated with this work on the Central Coast, and dividing this by the numbers of 16-year-old 'prevented smokers' (those who would have been expected to be smoking without the reduction observed), arrives at a cost of only \$100-200 to create a non-smoker this way, which is 5-10 times more cost effective than using nicotine replacement therapy to wean an adult smoker off nicotine (author's personal data). One cost is a public expenditure (enforcing law); the other is private (treating your own addiction).

This is an endeavour where we can get good gain for our money, but there could even be better value for our existing public dollar if some of the costs of policing a private tobacco industry were recovered from the industry itself, perhaps using some form of annual retailer registration fee. The potential to lose such a licence for infringements could be an added deterrent to illegal behaviour.

The history of law enforcement undertaken for health benefit going back to the Public Health Act of 1848 suggests a long held belief that it is effective in improving health. Unease about law enforcement can arise within health agencies because most people employed within health provide healing and individual comfort. This focus on warmth and helping is the basis of professional, nonjudgmental clinical services. At the other end of the personal interaction scale is zero tolerance policing, which some claim has cleaned up New York's streets. ${ }^{21}$ This approach aims to inflict pain on those prosecuted and to create nervousness in many who potentially could be.
Public health law enforcement may seem distasteful or old fashioned in an era of individual choice and high technology treatments. However, it still represents good value when we want to bring about large-scale community change. Investing in improving the legal and prosecution skills of our workforce will pay dividends.

\section{References}

1. South Eastern Sydney Area Health Service. History of Public Health in Australia. Sydney: South Eastern Sydney Area Health Service; DATE. Available from: http://www.sesahs. health.nsw.gov.au/public_health_unit/public_health_history.asp (Cited 10 December 2008.)

2. NSW Public Health Act 1991 No 10.

3. NSW Smoke-free Environment Act 2000 No 69.

4. Ling PM, Landman A, Glantz SA. It is time to abandon youth access tobacco programmes. Tob Control 2002; 11: 3-6. doi:10.1136/tc.11.1.3

5. Rigotti NA, DiFranza JR, Chang YC, Tisdale T, Kemp B, Singer DE. The effect of enforcing tobacco-sales laws on Adolescents' access to tobacco and smoking behaviour. N Engl J Med 1997; 337: 1044-51. doi:10.1056/ NEJM199710093371505

6. Bagott M, Jordan C, Wright C, Jarvis S. Test sales do not have impact on prevalence of smoking by children. BMJ 1997; 312 : 490-1.

7. Bagott M, Jordan C, Wright C, Jarvis S. How easy is it for young people to obtain cigarettes, and do test sales by trading standards have any effect? A survey of two schools in Gateshead. Child Care Health Dev 1998; 24: 207-16. doi:10.1046/j.1365-2214.1998.00066.x

8. NSW Health Department. Policies and Procedures for the enforcement of Section 59 of the Public Health Act 1991. North Sydney: NSW Health Department; 1997.

9. Commonwealth of Australia. A National Approach for Reducing Access to Tobacco in Australia by Young People under 18 Years of Age. Appendix B: Case Studies. Canberra: Commonwealth of Australia; 2000.

10. Robinson v Woolworths Ltd [2005] NSWCCA 426.

11. Robinson v Zhang [2005] NSWCA 439.

12. Tutt D, Bauer L, Edwards C, Cook D. Reducing adolescent smoking rates. Maintaining high retail compliance results in substantial improvement. Health Promotion Journal of Australia 2000; 10(1): 20-4.

13. Harris S. Shops still selling smokes to minors. Sunday Telegraph, Sydney; 8 September 1996: 24.

14. Sheehan M. Alcohol Controls and Drink Driving: the social context. Canberra: Federal Office of Road Safety; 1994: p. 31.

15. Roads and Traffic Authority (NSW). RTA Annual Report 2007. Sydney: Roads and Traffic Authority; 2007. Available from: http:/www.rta.nsw.gov.au/publicationsstatisticsforms/ downloads/2007_annual_report_dl1.html (Cited 11 July 2008.)

16. Australian Transport Safety Bureau. Monograph 5, Alcohol and road fatalities in Australia. Canberra: Australian Transport Safety Bureau; 1998.

17. NSW Liquor Regulation 2008: Division 1. 
18. McKnight AJ, Streff FM. The effect of enforcement upon service of alcohol to intoxicated patrons of bars and restaurants. Accid Anal Prev 1994; 26: 79-88. doi:10.1016/ 0001-4575(94)90070-1

19. Tilson M. A Critical Analysis of Youth Access Laws. Ottawa: Canadian Cancer Society; 2002: p. 33.

20. Australian Institute of Health and Welfare. 2004 National Drug Strategy Household Survey: First results. Canberra: AIHW; 2005.

21. Grabosky PN. Zero Tolerance Policing. Trends and issues in crime and criminal justice No 102. Canberra: Australian Institute of Criminology; 1999.

22. Hill D, White V, Segan C. Prevalence of cigarette smoking among Australian secondary school students in 1993. Aust J Public Health 1995; 19(5): 445-9.

23. Hill D, White V, Letcher T. Tobacco use among Australian secondary students in 1996. Aust N Z J Public Health 1999; 23(3): 252-9. doi:10.1111/j.1467-842X.1999.tb01252.x

24. Hill D, White V, Effendi Y. Changes in the use of tobacco among Australian secondary students: results of the 1999 prevalence study and comparisons with earlier years. Aust N Z J Public Health 2002; 26(2): 156-63. doi:10.1111/ j.1467-842X.2002.tb00910.x

25. White V, Hayman J. Smoking behaviours of Australian secondary students in 2002. National Drug Strategy Monograph Series No 54. Canberra: Australian Government Department of Health and Ageing; 2004.

26. White V, Hayman J. Smoking behaviours of Australian secondary students in 2005. National Drug Strategy Monograph Series No 59. Canberra: Australian Government Department of Health and Ageing; 2006.

27. Centre for Epidemiology and Research, NSW Department of Health. The health behaviours of secondary school students in New South Wales 2002. N SW Public Health Bull 2004; 15(S-2): 14-5. doi:10.1071/NB04S16

28. NSW Health. Tobacco. NSW Health: North Sydney; 2007. Available from: http://www.health.nsw.gov.au/PublicHealth/ surveys/hss/05/toc/14_beh_tobacco.asp (Cited 8 July 2008.) 


\section{Public health and regulation of the built environment}

\section{Stephen J. Corbett}

Centre for Population Health, Sydney West Area Health Service Email:stephen_corbett@wsahs.nsw.gov.au

The earliest public health statutes contrived to develop effective controls of the excesses of the rapid urban development that accompanied the industrial revolution. By the end of the 20th century, much responsibility for the regulation of the built environment has been dispersed across government and in so doing has moved beyond the gaze of everyday public health concern. This paper argues firstly that there is a strong justification for greater public health involvement in the ongoing regulation of the built environment and secondly that a much broader range of health impacts needs to be considered in the conception of these regulatory measures.

The Health of Towns Association was formed in London in 1844 following the publication of Edwin Chadwick's Report on the Sanitary Conditions of the Labouring Population. ${ }^{1}$ The Association was an important lobby group which supported the sanitary reforms which culminated in the first Public Health Act of 1848, the direct progenitor of public health legislation in Australia. Its stated aim was to:

\footnotetext{
... substitute health for disease, cleanliness for filth, order for disorder, economy for waste, prevention for palliation, justice for charity, enlightened self-interest for ignorant selfishness, and to bring to the poorest and meanest - Air, Water, Light. ${ }^{2}$
}

Nineteenth century sanitary reforms created a durable system of governance of what at first was a narrow but pressing set of hazards in the built environment; local authorities were vested with responsibility for building standards and town planning, the control of noxious trades, water supply, sewage disposal, the management of burials and mortuaries and vermin control.

Over the last 150 years the public health infrastructure, especially in developed countries, has grown in both size and complexity. Some of the major components of this infrastructure, as it applies to the built environment, are summarised in Table 1. The evolution of this infrastructure is shaped by population growth, technological innovation, community expectations, environmental and resource constraints and importantly the national and international experience of regulatory and system failure, and disaster.

Responsibility for managing these hazards is now dispersed across government. ${ }^{3}$ Public health professionals have less involvement in the day-to-day management of these hazards than environmental scientists, traffic engineers, building-safety experts and professional urban planners. ${ }^{4}$ Regulatory oversight is similarly fragmented and in this situation it is easy for those working outside of the health system to lose sight of public health regulatory objectives.

There is however a strong justification for continued regulation of the built environment for public health, and for a more explicit role for public health agencies and professionals in defining or redefining public health objectives, in setting standards and in regulatory decision making. ${ }^{4}$ This role would or could include:

(a) An insistence on fidelity to the technical merits of policy proposals. ${ }^{5}$ Public health is not a self-evident virtue, and there is an active critique of the over-involvement of government in the everyday lives of citizens. At times there is a need to take a strong position, supported by evidence, to impose some controls on a new consumer product or to contest a policy proposal. By adherence to technical merits we mean a close examination of the feasibility, effectiveness and efficiency of proposed regulations. The recent technical and policy debate about the health effects of unflued gas heaters in Australian homes demonstrated the need for robust public health arguments to inform important decisions about energy use and sustainability. ${ }^{6}$

(b) Enabling the consideration of a much broader range of health impacts of urban planning, transport or building proposals. As Table 1 demonstrates, the regulatory framework for the built environment has been shaped largely by concerns about safety and injury prevention and communicable disease risk, and not by concerns about chronic disease prevention (cancer prevention and tobacco control are an exception). In many cases, these concerns can be addressed by an extension of current practice: for 
Table 1. Regulatory response and responsibility for hazards in the built environment

\begin{tabular}{|c|c|c|c|}
\hline \multirow[t]{2}{*}{ Hazard } & \multicolumn{2}{|c|}{ Public health infrastructure } & \multirow[t]{2}{*}{ Regulatory domain } \\
\hline & Policy and legislation & Physical Infrastructure & \\
\hline $\begin{array}{l}\text { Airborne infection } \\
\text { and overcrowding }\end{array}$ & $\begin{array}{l}\text { Tenancy laws } \\
\text { Fire safety codes } \\
\text { Floor space provision } \\
\text { Building codes } \\
\text { Ventilation standards }\end{array}$ & $\begin{array}{l}\text { Windows } \\
\text { Ceiling Heights }\end{array}$ & $\begin{array}{l}\text { Consumer protection } \\
\text { Fire Brigade } \\
\text { Public Health Act } \\
\text { Local government } \\
\text { Building Codes Board } \\
\text { Australian Standards }\end{array}$ \\
\hline Water borne diseases & $\begin{array}{l}\text { Drinking and waste-water } \\
\text { standards } \\
\text { Plumbing codes } \\
\text { Catchment protection }\end{array}$ & $\begin{array}{l}\text { Drinking and waste-water } \\
\text { infrastructure }\end{array}$ & $\begin{array}{l}\text { Catchment authorities } \\
\text { Water utilities } \\
\text { Water utilities }\end{array}$ \\
\hline Noise & Building codes & & Environment protection \\
\hline Chemical hazards & $\begin{array}{l}\text { Zoning laws } \\
\text { Product labelling and material } \\
\text { data safety sheets }\end{array}$ & Childproof containers & $\begin{array}{l}\text { Health and safety } \\
\text { Consumer protection } \\
\text { Dangerous goods }\end{array}$ \\
\hline $\begin{array}{l}\text { Crime and violence } \\
\text { prevention }\end{array}$ & & Street lighting & Urban planning \\
\hline Injury & & $\begin{array}{l}\text { Safety barriers } \\
\text { Road surfacing }\end{array}$ & Roads and transport \\
\hline Transport & Vehicle safety standards & & Roads and transport \\
\hline Insects and vermin & Building code & & Local government \\
\hline
\end{tabular}

Table 2. Examples of regulatory proposals directed at reducing risks of chronic disease

\begin{tabular}{|c|c|c|}
\hline Risk factors & Regulatory domain & Regulatory proposals \\
\hline \multirow[t]{4}{*}{$\begin{array}{l}\text { Obesity, physical activity } \\
\text { and nutrition }\end{array}$} & Land use planning & $\begin{array}{l}\text { Removal of provisions for the co-location of fuel and food } \\
\text { outlets, a convention which embeds car dependence for } \\
\text { even the shortest journeys }\end{array}$ \\
\hline & & $\begin{array}{l}\text { State Environment Planning Policy (SEPP) for walkability } \\
\text { in new developments }\end{array}$ \\
\hline & & $\begin{array}{l}\text { Making retail tenancy arrangements conducive to the } \\
\text { local availability of fresh food }\end{array}$ \\
\hline & Open space provision & $\begin{array}{l}\text { Codification of minimal open space quality and quantity } \\
\text { requirements for new developments }\end{array}$ \\
\hline \multirow[t]{3}{*}{ Noise } & Transport & Minimum setbacks from major roadways \\
\hline & & Adopting noise reducing technology for tyes and road surfacing \\
\hline & Building codes & Increasing noise mitigation specifications near busy roadways \\
\hline \multirow[t]{2}{*}{ Air quality } & Transport & Minimum setbacks from major roadways \\
\hline & Building codes & $\begin{array}{l}\text { Reduced indoor air pollutants specified in as the recently } \\
\text { introduced NSW Building Sustainability Index (BASIX) }\end{array}$ \\
\hline
\end{tabular}

example, while pedestrian safety will be a normal inclusion in any development proposal, explicit consideration of the extent to which a proposal encourages walking could easily be appended. ${ }^{4}$

(c) Proposing regulatory solutions to contemporary public health problems. The obesity epidemic and its links to sedentary lifestyles and, perhaps, to an urban form which predicates reductions in levels of physical activity have thrown open a debate about regulatory intervention for health in land use and urban planning. Prescriptive requirements for the location and number of fast food outlets and fresh food retailers and the mandating of urban residential densities have been proposed. A more promising 
approach may be an ongoing review of existing ordinances for pedestrian and cycling throughways, zoning, and lot size and layout. With this caveat in mind some examples of regulatory responses to contemporary public health responses are set out in Table 2.

(d) Being advocates and advisers in the public debates around climate change, sustainability and urban planning and the excesses of consumerism. The interactions between humans and their environment is complex and public health officials are well placed to provide a balanced perspective on acute and contingent health risks. Urban planning decisions in particular have the potential to shape ordinary lives over decades and the precautionary principle has special application to the health evidence used for or against specific proposals.

Our society has a vast fixed investment in public health infrastructure in the built environment: sewers, water treatment plants and storage facilities, road surfacing and engineering, public transport, building design and construction, consumer and product safety measures, fire prevention and waste disposal - all measures which underpin our health. In general these provisions do their work silently and are well accepted by the public. At the moment of their imposition there may be suspicion or alarm - there was a furious 20-year debate in Sydney about the building of the highly visible and ornate vents for Sydney's sewer system $^{7}$ - but, in time, if appropriate, these provisions will gain acceptance. The complexity of modern government should not deter public health officials from seeking out new regulatory approaches to the built environment for disease prevention.

\section{References}

1. Chadwick E. Report on the sanitary condition of the labouring population of Great Britain 1842. Edinburgh: Edinburgh University Press; 1965.

2. Centre for History in Public Health, London School of Hygiene and Tropical Medicine. Healthy Towns, Healthy Cities: Public Health in British Cities, 1844-2004. Conference Report. London: London School of Hygiene and Tropical Medicine; 2004. Available at: http://www.lshtm.ac.uk/ history/healthoftowns.html (Cited 11 September 2008.)

3. Giddens A. Risk - Hong Kong. 1999 Reith Lectures:Runaway World: BBC, 1999. Available at: http://www.bbc.co.uk/radio4/ reith1999/lecture2.shtml (Cited 11 September 2008.)

4. Perdue WC, Gostin LO, Stone LA. Public health and the built environment: historical, empirical and theoretical foundations for an expanded role. J Law Med Ethics 2003; 31: 557-66. doi:10.1111/j.1748-720X.2003.tb00123.x

5. Landy MK, Roberts MJ, Thomas SR. The Environment Protection Agency: asking the wrong questions from Nixon to Clinton. New York: Oxford University Press; 1994.

6. enHealth Council. The health effects of unflued gas heater use in Australia. Commonwealth of Australia, 2007. Available at: http://aodgp.gov.au/internet/main/publishing.nsf/Content/ ohp-enhealth-unflued-gas-heater-cnt.htm (Cited 11 September 2008.)

7. Beder S. From sewage farms to septic tanks: trials and tribulations in Sydney. J R Aust Hist Soc 1993; 79(1\&2): 72-95. 


\section{Responding to the challenges of HIV prevention in NSW}

\section{Melissa J. Irwin', John C. Imrie ${ }^{\mathrm{B}}$, Barry Edwards ${ }^{\mathrm{C}}$ and Stevie Clayton ${ }^{\mathrm{D}}$}

${ }^{\mathrm{A}}$ NSW Public Health Officer Training Program, NSW Department of Health

${ }^{\mathrm{B}}$ National Centre for HIV Social Research, University of NSW

${ }^{\mathrm{C}}$ HIV/AIDS \& Related Programs Unit, South Eastern Sydney Illawarra Area Health Service

${ }^{\mathrm{D}}$ AIDS Council of NSW

Human immunodeficiency virus (HIV), the virus that causes acquired immune deficiency syndrome (AIDS), represents one of the greatest public health challenges of our time. Despite a global shift towards generalised epidemics, a rapid and sustained response has been effective in containing the New South Wales (NSW) epidemic to low levels of infection largely within identifiable at-risk populations. ${ }^{1}$ Some of the reasons for this success are thought to include: effective partnerships between government, community, researchers and clinicians responding to HIV; use of an evidence-based policy platform; integration of behavioural, clinical and epidemiological data to better understand HIV trends and to develop responses; sustained investment in HIV prevention programs; and maintenance of a skilled workforce. ${ }^{1}$

\section{Trends in HIV surveillance in NSW}

The first Australian case of AIDS was diagnosed in NSW in 1982. ${ }^{2}$ At the end of 2007, there were 14803 new HIV notifications in NSW residents, with 404 in 2007 alone. Males account for at least $92 \%$ of notifications, with the highest proportion in the age group 30-39 years. The greatest risk factor for transmission in NSW continues to be sexual contact between men who have sex with men (MSM). ${ }^{3}$

Since 2000, the World Health Organization (WHO) and the United Nations Joint Programme on HIV/AIDS (UNAIDS) have promoted the use of second generation HIV surveillance. ${ }^{4}$ This strategy focuses on examining biological and behavioural data (including evaluation data from prevention, treatment and care programs) concurrently to explain observed disease trends. This form of expanded surveillance is intended to provide better information for action and to guide timely and evolving HIV prevention responses.

Recent trends in the rates of newly diagnosed HIV have differed between Australian jurisdictions. From 2002 to 2006, NSW observed a stable rate of approximately
6.1/100 000 population (5.9/100000 in 2006), whereas Queensland, South Australia, Victoria and Western Australia all observed increasing rates, from 3.5, 2.0, 4.5 and 2.4/100 000 in 2002 to 4.0, 4.1, 5.6 and 3.5/100 000 population, respectively, in 2006. ${ }^{5}$ A NSW HIV Think Tank, held in mid 2007, brought experts in HIV epidemiology, clinical and behavioural research together with leaders from the HIV community response, clinicians and NSW Health agencies to investigate the reasons for the differences in these state trends. ${ }^{1}$ The Think Tank used a second generation surveillance approach to compare trends in Queensland and Victoria with NSW. These jurisdictions showed the most marked differences and had the most comprehensive behavioural and clinical data available for comparison.

A stabilisation and subsequent decline in reported rates of unprotected anal intercourse with casual partners among MSM (including HIV-positive men) from 2001 to 2006, was identified as the single most important, but not the only, explanation for the observed NSW trend. ${ }^{1}$ This trend was not observed in Queensland or Victoria. Other trends in sexual practice, disclosure of HIV status and frequency of HIV and sexually transmissible infection (STI) testing among MSM may have also contributed to differences in HIV notifications in eastern Australian states.

\section{The HIV response in NSW}

The partnership approach to HIV in NSW has ensured collaboration between government, affected communities, researchers and clinicians. The NSW HIV/AIDS Strategy 2006-2009 provides the government framework for HIV health promotion; treatment and care; and infrastructure and support in NSW. ${ }^{6}$ It identifies the current priority populations as gay and other homosexually active men; people living with HIV/AIDS; people from culturally and linguistically diverse backgrounds; Aboriginal people; people who inject drugs; and sex workers.

Area health services and community-based organisations within NSW work collaboratively to provide a comprehensive range of HIV prevention and care services. Area health services have HIV/AIDS and Related Program Units, which provide HIV and sexual health promotion; Aboriginal sexual health worker positions; and harm reduction strategies, such as needle and syringe exchange programs. Communitybased organisations, including the AIDS Council of NSW, are also funded by government to provide HIV prevention, education and health promotion, treatment, care and support, policy, advocacy and community mobilisation. 
An example of collaborative practice in NSW is the STIs in Gay Men Action Group (STIGMA), which brings together general practitioners, researchers, area surveillance, health promotion officers and community organisations to plan and implement prevention, testing and treatment programs. Among other initiatives, STIGMA has developed well-accepted STI testing guidelines for general practitioners, social marketing programs to remind MSM about STI testing, and innovative online mechanisms to encourage contact tracing by those who have been diagnosed with an STI.

Many of the findings related to the NSW HIV Think Tank have now been published in a special edition of Sexual Health titled 'HIV in Australia'?

\section{References}

1. NSW Department of Health. A Think Tank: Why are HIV notifications flat in NSW 1998-2006. Sydney: NSW Department of Health; 2007: p. 11.

2. Stewart K, Penny R. Containing HIV in NSW: A world class success. N S W Public Health Bull 2003; 14(3): 57-9. doi:10.1071/NB03018
3. Communicable Diseases Branch, NSW Department of Health NSW HIV/AIDS database, Communicable Diseases Branch, NSW Department of Health. New HIV notifications in people who were NSW residents at the time of diagnosis, by year of diagnoses and case characteristics. North Sydney: NSW Health; 2007. Available from: http://www.health.nsw.gov.au/ resources/publichealth/infectious/diseases/hiv_aids/ fianl_2007_hiv.pdf (Cited 3 July 2008.)

4. WHO and UNAIDS. Guidelines for Second Generation HIV Surveillance. Report No: WHO/CDS/CSR/EDC/2000.5, UNAIDS/00.03E. Geneva: WHO and UNAIDS; 2000: p. 40. Available from: http://www.who.int/hiv/pub/surveillance/ en/cds_edc_2000_5.pdf (Cited 3 July 2008.)

5. National Centre in HIV Epidemiology and Clinical Research. HIV/AIDS, viral hepatitis and sexually transmissible infections in Australia Annual Surveillance Report 2007. Sydney: National Centre in HIV Epidemiology and Clinical Research, The University of New South Wales; Canberra: Australian Institute of Health and Welfare; 2007: p. 147.

6. NSW Department of Health. NSW HIV/AIDS Strategy 2006-2009. Sydney: NSW Department of Health; 2006: p. 31.

7. HIV in Australia. Sexual Health 2008; 5(2):89-210. Available at: http://www.publish.csiro.au/nid/166/issue/4202.htm (Cited 3 July 2008.) 


\section{Rubella}

\section{What is rubella?}

Rubella (or German measles) is an infectious viral disease of humans. Although in most people infection is mild, infection in early pregnancy can cause serious birth defects or miscarriage.

\section{What is congenital rubella syndrome?}

- Congenital rubella syndrome occurs in up to $90 \%$ of babies born to women who are infected with rubella during the first 3 months of their pregnancy.

- Congenital rubella syndrome can cause birth defects, including heart defects, deafness, brain damage and eye problems such as cataracts.

\section{What are the symptoms?}

- The symptoms of rubella may include a mild fever, rash, runny nose, sore throat and often swollen lymph node. Aching joints are also common, especially in women.

- In rare cases, rubella infection can be complicated by lowering of the platelet count (thrombocytopenia), which can cause bleeding, or by encephalitis (inflammation of the brain).

\section{How is it spread?}

- Rubella is spread from an infected person by droplets from the nose or mouth or by direct contact. Rubella is easily spread to people who have not been vaccinated or previously infected.

- The time from exposure to onset of illness is usually 14 to 21 days. People with rubella are usually infectious from 7 days before the rash occurs until 4 days later.

\section{Who is at risk?}

Anybody who is not immune (either from past infection or vaccination) is at risk of rubella.

\section{How is it prevented?}

- People with rubella should stay at home for at least 4 days after onset of rash, and avoid contact with non-immune people.

- The best protection against rubella is through vaccination with MMR vaccine, which protects against infection with measles, mumps and rubella.

- MMR vaccine should be given to children at 12 months and at 4 years of age. Two doses of MMR provides protection against rubella to over $99 \%$ of those vaccinated.
- MMR vaccine is a safe and effective vaccine that has been used worldwide for many years.

- While many older adults are immune to rubella because they have been vaccinated or infected as children, young adults (especially men) may not be immunised. Vaccination against rubella is very important for women (and men) of childbearing age in reducing the chance of pregnant women coming into contact with, and contracting, rubella infection.

- It is very important for all women planning a pregnancy to know whether they are immune to rubella. Women planning a pregnancy should have a blood test, which can be done by their local doctor, to check that they are protected against rubella. Rubella vaccine should not be given to pregnant women and pregnancy should be avoided for 1 month following vaccination.

\section{How is it diagnosed?}

Rubella can be difficult to diagnose because there are many other viruses that cause similar illnesses with a fever and a rash. Definite diagnosis requires a blood test.

\section{How is it treated?}

Treatment for the symptoms of rubella include rest and plenty of fluids.

\section{What is the public health response?}

Pregnant women who have come in contact with a case of rubella should call their doctor for advice. Rubella is notifiable by laboratories in NSW under the Public Health Act. Statistics on the number of cases are tracked to monitor the impact of the immunisation program, and to identify outbreaks.

For more information please contact your doctor, local public health unit or community health centre.

This fact sheet is available at: http://www.health.nsw.gov.au/ factsheets/infectious/rubella.html

\section{NSWOHEALTH}




\section{Communicable Diseases Report, NSW, September and October 2008}

\section{Communicable Diseases Branch, NSW Department of Health}

For updated information, including data and facts on specific diseases, visit http://www.health. nsw.gov.au and click on Infectious Diseases or access the site directly at: http://www.health.nsw. gov.au/publichealth/infectious/index.asp.

Figure 1 and Tables 1 and 2 show reports of communicable diseases received through to the end of October 2008 in New South Wales (NSW).

\section{Mumps}

Six cases of mumps were notified in September and a further two cases were notified in October, bringing the total number of cases to 82 in NSW this year. This is a significant reduction from 2007, where more than 300 cases were notified. However, as infection often occurs with minimal symptoms, the true number of cases is likely to be higher than reported in all years.

Mumps is a vaccine-preventable disease spread by droplet infection and direct contact with the saliva of people with the infection. Maximum infectiousness occurs from 2 days before to 4 days after onset of illness.

Symptoms include fever, loss of appetite, tiredness and headaches followed by swelling and tenderness of the salivary glands. One or both of the parotid salivary glands (in front of and below the ears) are often affected.

Mumps is usually a more severe illness in people infected after puberty. Complications are uncommon but can include encephalitis, meningitis, hearing loss, orchitis in post-pubertal boys and men, and ovarian inflammation in women.

To help prevent the spread, exclusion of people with mumps from work, school, child care and other settings is currently recommended for up to 9 days from the onset of swelling or until fully recovered, whichever is sooner. Immunisation against mumps takes place with the measles, mumps, rubella (MMR) vaccine, which is given routinely at 12 months and 4 years of age.

\section{Hepatitis D}

One case of hepatitis D was notified in September, and a further case was notified in October, bringing the total number of cases to 11 in NSW this year. This is close to the average for recent years.

Hepatitis $D$ is a rare infection that occurs only in people who already have hepatitis B virus (HBV) infection. Its importance lies particularly in the fact that co-infection with both viruses means greater risk of severe liver disease, including severe acute hepatitis, which can progress to chronic disease.

The modes of transmission for hepatitis D are similar to that for hepatitis B: exposure to infected blood and serous body fluids, contaminated needles, syringes or blood- and plasma-product transfusions. Sexual transmission may also occur but is less common than with HBV infection. Perinatal infection is rare. Infection may occur at the same time as a new HBV infection (co-infection) or when a person already infected with HBV develops chronic infection (super-infection). ${ }^{1}$

There is no vaccine for hepatitis $\mathrm{D}$, however, vaccination against hepatitis B prevents hepatitis D virus infection.

\section{Shigella}

An increase was detected in the number of shigellosis cases notified in NSW in September and October. Twelve men, mostly residents of inner Sydney, were notified with Shigella sonnei biotype $\mathrm{g}$ infection. A similar increase in Sh. sonnei biotype g was also recently detected in Victoria. These cases shared an unusual antibiotic-resistance pattern, which suggested that all of the cases were epidemiologically related.

Nine of the NSW cases were interviewed using a semi-structured, hypothesis-generating questionnaire. Interviewed cases reported illness lasting typically 6 to 7 days. Three cases required intravenous rehydration and antibiotics were prescribed for seven cases. No cases 
reported travel either overseas or outside of NSW in the 7 days prior to onset. There were no common food exposures. One case reported contact with another ill person. None of the cases identified recent contact with someone with shigellosis.

All interviewed cases were men who have sex with men. Seven cases reported having sex in the 3 days prior to onset with one to five partners. Two cases attended sex on premises venues. Three cases attended private sex parties and two reported sexual activity at home. Six cases reported oral and anal sex, and four cases reported oroanal sex.

All isolates were resistant to antibiotic treatment with streptomycin, sulphonamide, tetracycline, trimethoprim and naladixic acid, and had a reduced susceptibility to ciprofloxacin. This was the same resistance pattern as the Victorian isolates.

Alerts were published in Sydney's gay newspapers, advising people to avoid infection and seek treatment if they become sick. Alerts were faxed to general practitioners in metropolitan Sydney with advice to request stool specimens and test for shigellosis in men who have sex with men who present with diarrhoea.

No epidemiological links were identified between cases. Knowledge of shigellosis, and the transmission of Shigella, was poor and few men identified that some sexual practices could be a risk factor for infection. Further work is recommended with this community to raise awareness of bacterial pathogens and prevention strategies.

All shigellosis infections should be treated for public health reasons as only a small inoculum is required for the infection to be transmitted to another person. Current Australian therapeutic guidelines recommend first-line treatment with norfloxacin, trimethoprim or ampicillin. As ampicillin is no longer available as an oral preparation in Australia, amoxycillin was identified as a suitable alternative for the purposes of treating cases related to this outbreak.

Shigellosis can be prevented by maintaining good general hygiene, including washing hands thoroughly after going to the toilet, after having sex and before eating. People with new onset diarrhoea should avoid having sex while they are unwell and should not prepare food for others.

\section{Reference}

1. CD Section, Public Health Group, Victorian Department of Human Services. The Blue Book - Guidelines for the control of infectious diseases. Melbourne: State of Victoria; 2005. Available from: http://www.health.vic.gov.au/ideas/bluebook (Cited 10 November 2008). 
Figure 1. Reports of selected communicable diseases, NSW, January 2004 to October 2008, by month of onset. Preliminary data: case counts in recent months may increase because of reporting delays. Laboratory-confirmed cases only, except for measles, meningococcal disease and pertussis. BFV, Barmah Forest virus infection; RRV, Ross River virus infection; lab conf, laboratory confirmed; Men $\mathrm{Gp} C$ and $\mathrm{Gp} B$, meningococcal disease due to serogroup $C$ and serogroup B infection; other/unk, other or unknown serogroups.

NB: Multiple series in graphs are stacked, except gastroenteritis outbreaks.

NB: Outbreaks are more likely to be reported by nursing homes and hospitals than by other institutions.

\begin{tabular}{|lc|}
\hline \multicolumn{2}{|c|}{ NSW Population } \\
Male & $50 \%$ \\
$<5$ y & $7 \%$ \\
$5-24$ y & $27 \%$ \\
$25-64$ y & $53 \%$ \\
$65+y$ & $13 \%$ \\
Rural & $46 \%$ \\
\hline
\end{tabular}
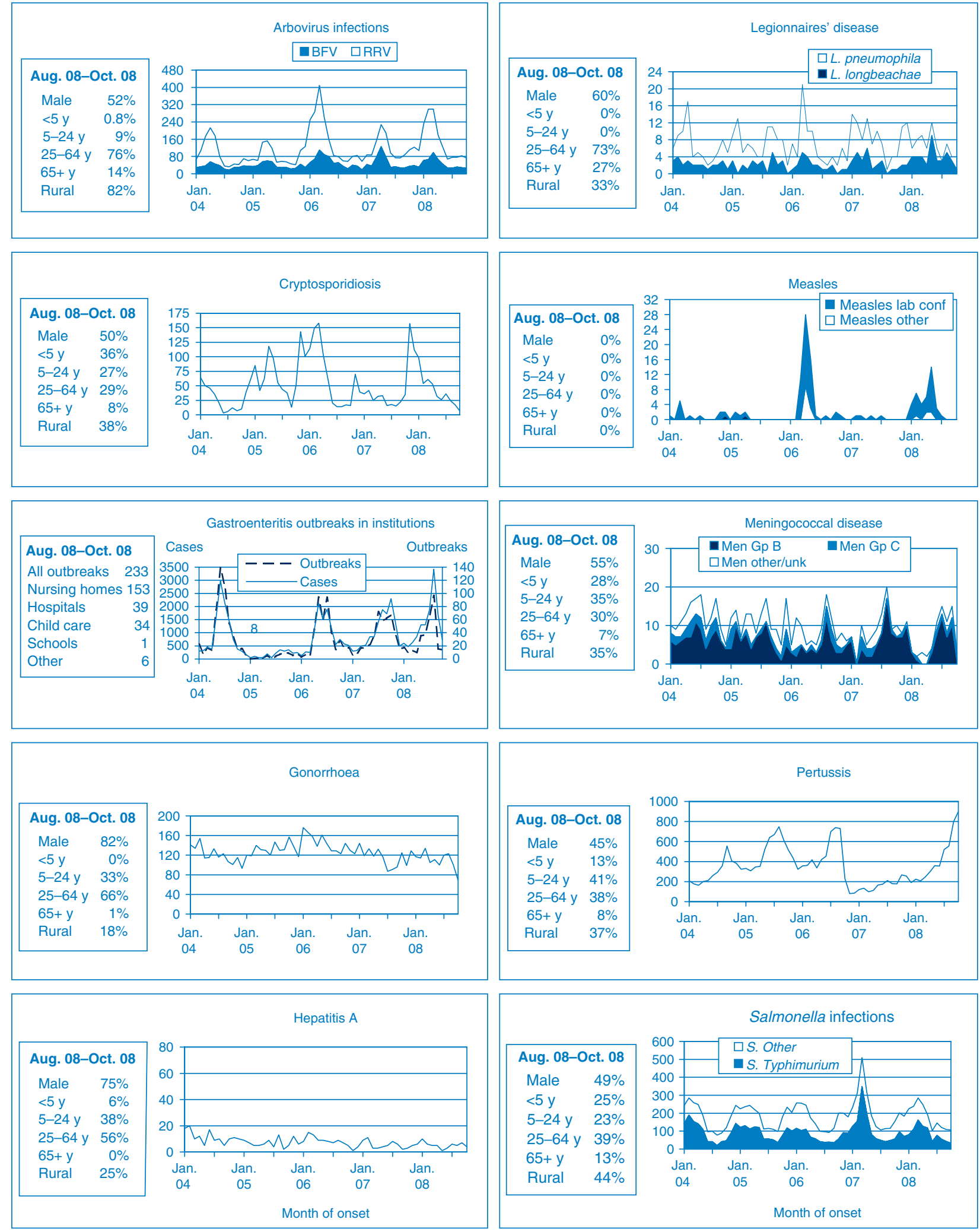


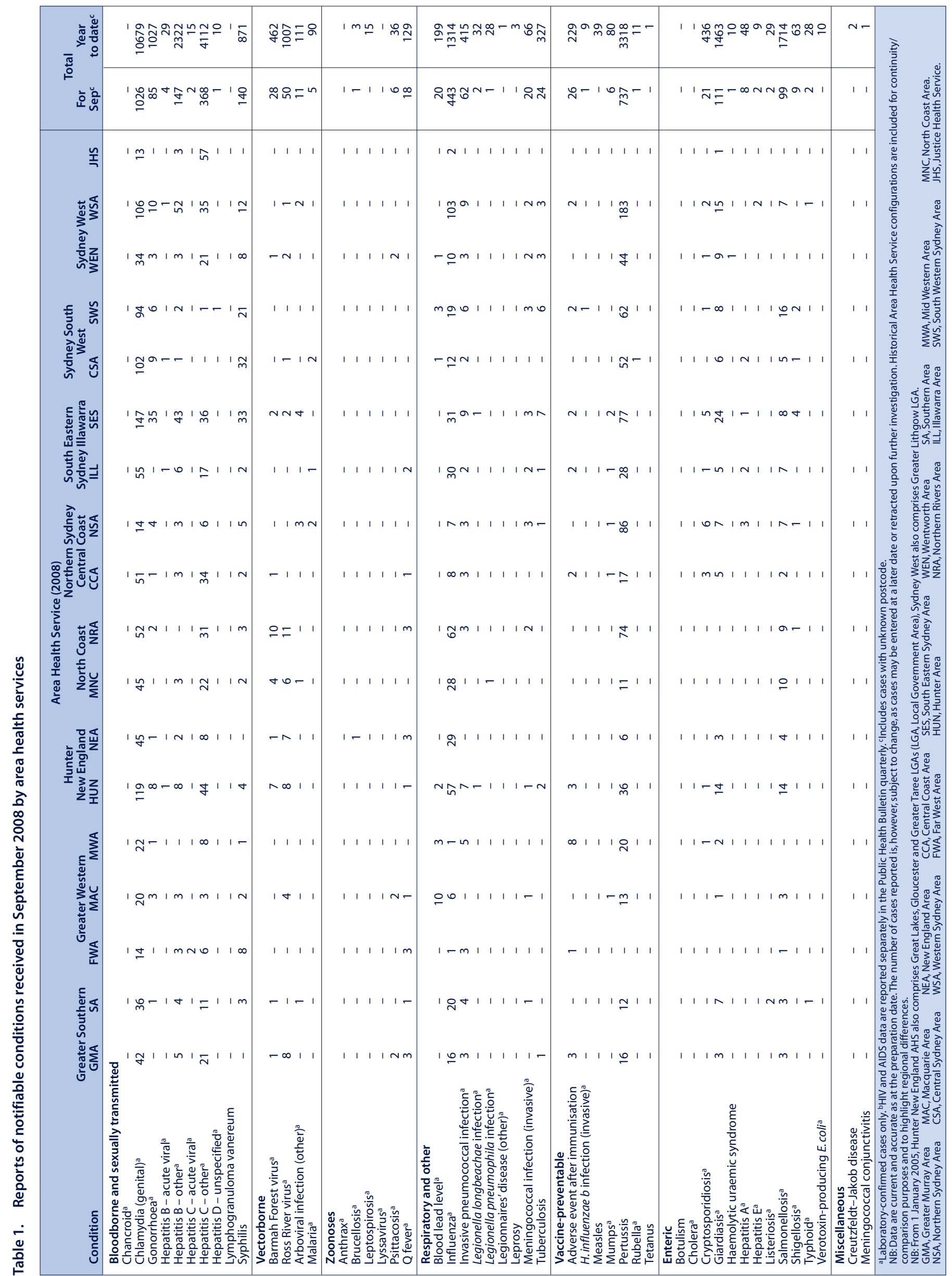




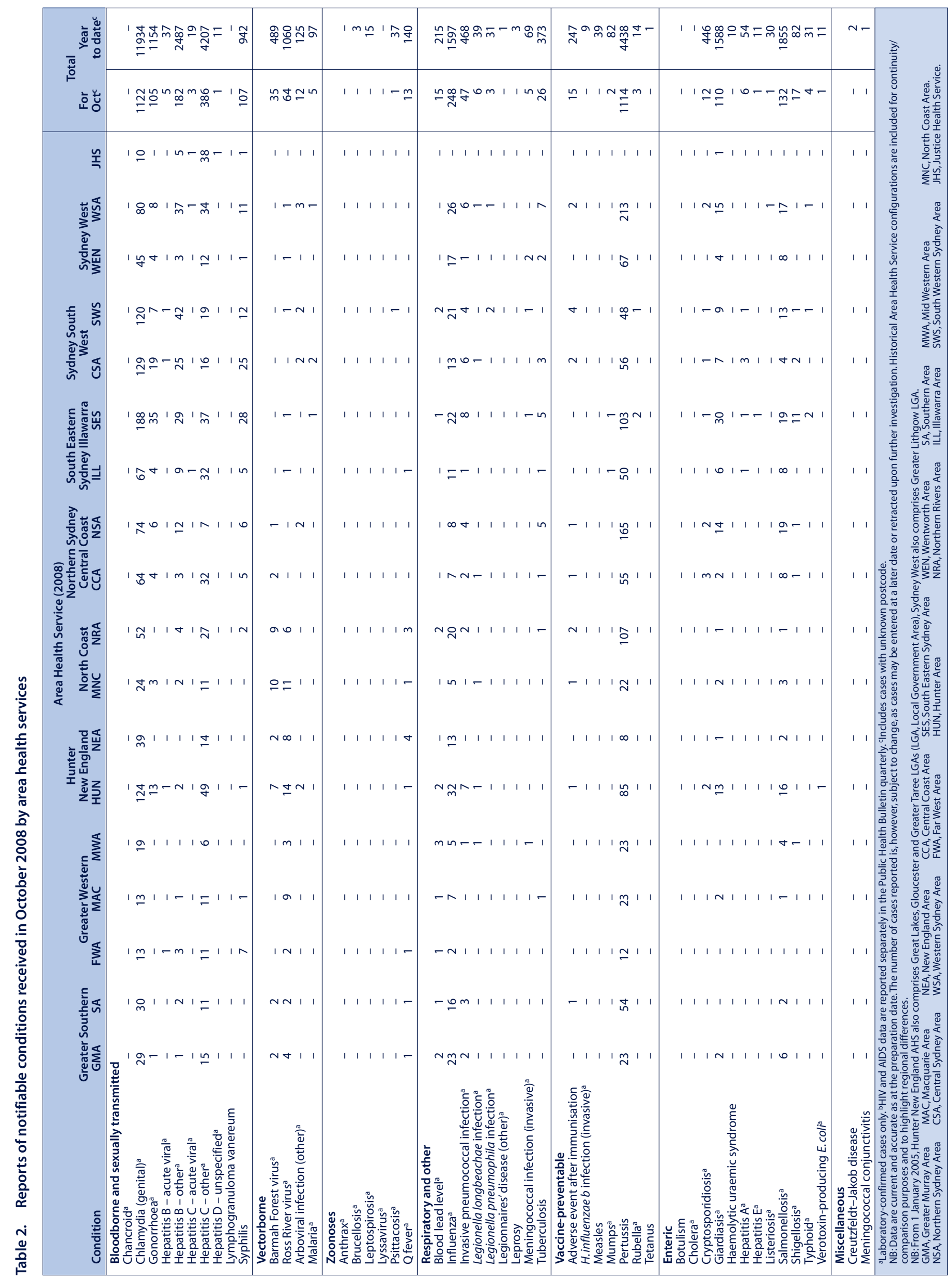




\section{NSW Public Health Bulletin Subscription Form and Electronic Early Alert Service}

To subscribe to the hard copy of the NSW Public Health Bulletin or to change your subscription details please complete this form and return it by email (phbulletin@doh.health.nsw.gov.au) or fax (61 293919232 ).

The Bulletin can be accessed electronically from www.publish.csiro.au/journals/phb. Subscribe to the Early Alert service to be notified as soon as it appears online (http://publish.csiro.au/nid/226.htm?nid=25\&aid=685).

\section{Subscription information}

I wish to receive the NSW Public Health Bulletin:

My details are as follows

Name:

Organisation:

Mailing Address:

State: Postcode: Country:

Telephone: Facsimile:

Email:

\section{Change of Address}

$\square$ I wish to change my mailing details, as follows:

Name:

From: [Insert old address]

To: [Insert new address] 


\section{Contents}

\section{Special issue: Regulation}

\section{Guest editorial}

193 Regulation and regulatory effectiveness in public health Introduces articles in this issue that provide evidence of the growing awareness of the potential of modernised and effective public health regulation.

Stephen J. Corbett

\section{Perspective}

195 Regulation for chronic disease control: the pathfinder role of tobacco

Reviews the evolution of tobacco control as an example of a regulatory approach to chronic disease prevention.

Andrew Penman

199 Regulation of research through research governance: within and beyond NSW Health

Argues for the effective and consistent implementation of research governance for quality research, both within NSW Health and nationally.

Geoffrey S. Bloom, Deborah Frew

203 Ensuring safe drinking water in regional NSW: the role of regulation

Discusses the NSW Health Drinking Water Monitoring Program's contribution to improved management of regional water supplies and its potential to support smaller water supply systems.

Paul M. Byleveld, Michelle A. Cretikos, Sandy D. Leask, David N. Durrheim
208 Enforcing law on tobacco sales to minors: getting the question and action right

Describes the Central Coast experience with enforcement of legislation for underage tobacco selling and the positive effect on smoking prevalence among young people; proposes future directions in tobacco regulation.

Douglas C.Tutt

\section{Perspective}

212 Public health and regulation of the built environment Reviews history of the effectiveness of public health regulation in addressing health hazards in the built environment; argues for an expanded role of regulation to address emerging public health issues such as chronic disease.

Stephen J. Corbett

Bug Breakfast in the Bulletin

215 Responding to the challenges of HIV prevention in NSW Melissa J. Irwin, John C. Imrie, Barry Edwards, Stevie Clayton

Factsheet

217 Rubella

Communicable Diseases Report, NSW

218 September and October 2008

\section{NSW PUBLIC HEALTH BULLETIN}

The NSW Public Health Bulletin is a peer-reviewed journal produced by the NSW Department of Health and indexed in Medline. It has a NSW focus, however, it aims to support the practice of public health more broadly.

\section{Editor}

Dawn Simpson

\section{Editorial correspondence}

Please address all correspondence and submissions to:

The Editor, NSW Public Health Bulletin Locked Mail Bag 961

North Sydney NSW 2059 Australia

Email:phbulletin@doh.health.nsw.gov.au

Telephone: +61 294245876

Fax: +61 293919232

\section{Submission of articles}

The Bulletin accepts proffered and commissioned articles along with short reports, on all aspects of public health. Articles should be 1500-2000 words, not including tables and figures, and should include an abstract of up to 100 words. Articles should follow the journal style and layout as closely as possible, as described in the Instructions to Authors. Articles should be emailed in a Word for Windows format to: phbulletin@doh.health.nsw.gov.au, and should be accompanied by a covering letter signed by all authors and a License to Publish. The Instructions to Authors, License to Publish and other useful information can be downloaded from the Bulletin website.

\section{Distribution}

The Bulletin is freely available from the Bulletin website. Copies of the current issue and back issues can be downloaded in both PDF and HTML formats. If you would like to be notified when new issues of the Bulletin are available online, subscribe to the early alert email system at the Bulletin website. The early alert email contains the contents of each new issue along with electronic links to the articles. To receive a printed copy of the Bulletin, subscribe online at the Bulletin website, or contact your local public health unit or the editorial office. eISSN 1834-8610

Website: www.publish.csiro.au/journals/phb Copyright @ 2008 NSW Department of Health 